\title{
Nitrogen and phosphorus retention estimated independently by flux measurements and dynamic modelling in the estuary, Randers Fjord, Denmark
}

\author{
Kurt Nielsen $^{1, *}$, Nils Risgaard-Petersen ${ }^{2}$, Bent Sømod ${ }^{3}$, Søren Rysgaard ${ }^{1}$, Tony Bergø \\ ${ }^{1}$ National Environmental Research Institute, Department of Lake and Estuarine Ecology, Vejlsøvej 25, PO Box 314, \\ 8600 Silkeborg, Denmark \\ ${ }^{2}$ Aarhus University, Department of Microbial Ecology, Ny Munkegade, Building 540, 8000 Aarhus C, Denmark \\ ${ }^{3}$ Aarhus County, Environmental Department, Lyseng Allé, 8270 Højbjerg, Denmark \\ ${ }^{4}$ Water Consult, Stendyssevej 24b, 4171 Glumsø, Denmark
}

\begin{abstract}
Nutrient retention was studied in the Danish estuary Randers Fjord, using 2 independent methods: (1) measurement of denitrification and nutrient flux rates across the sediment-water interface, and (2) estimations of mass balance established on the basis of hydrodynamic modelling (MIKE 12). Annual N retention estimated by hydrodynamic modelling was $460 \mathrm{t} \mathrm{N} \mathrm{yr}^{-1}$. Direct measurements suggested that $60 \%$ of the retained $\mathrm{N}$ was denitrified. Despite high area-based denitrification rates $\left(0.1\right.$ to $8 \mathrm{mmol} \mathrm{N} \mathrm{m}^{-2} \mathrm{~d}^{-1}$, or on average $\left.140 \mathrm{~kg} \mathrm{~N} \mathrm{ha}^{-1} \mathrm{yr}^{-1}\right)$ the majority of the $\mathrm{N}$ freshwater input $(90 \%)$ was exported to the open sea, the Kattegat. The model suggested maximum $\mathrm{N}$ retention in March and February, and our data indicate that $\mathrm{N}$ retention was mainly caused by sedimentation of freshwater allochthonous organic $\mathrm{N}$ in the inner part of the estuary. Annual $\mathrm{P}$ retention estimated by hydrodynamic modelling was $15 \mathrm{t} \mathrm{P} \mathrm{yr}^{-1}$, corresponding to $9 \%$ of the freshwater input.

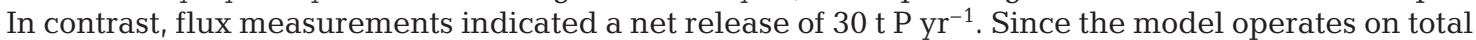
$\mathrm{P}$ and the flux measurements only included fluxes of $\mathrm{PO}_{4}{ }^{3-}$, this significant difference was most probably due to sedimentation of allochthonous organic matter. Simple models used in previous studies of estuarine nutrient retention and denitrification could not explain our data. We tested a model reported in the literature for nitrogen and phosphorus retention as a function of freshwater residence time. Using this model, nitrogen retention was 1.6 times higher than that estimated by our model, while the phosphorus model predicted a $3 \%$ release, compared to $9 \%$ retention estimated by our model. Models that estimate denitrification from $\mathrm{NO}_{3}{ }^{-}$concentrations in the water column and $\mathrm{O}_{2}$ uptake in the sediment explained less than $7 \%$ of the annual and spatial variations of denitrification in Randers Fjord. Regulation of denitrification seemed to be more complex in Randers Fjord and, consequently, direct measurements or complex modelling will have to be applied to obtain reliable estimates of retention.
\end{abstract}

KEY WORDS: Estuary · Eutrophic $\cdot$ Nitrogen $\cdot$ Phosphorus $\cdot$ Retention $\cdot$ Denitrification $\cdot$ Mass balance $\cdot$ Dynamic modelling

Resale or republication not permitted without written consent of the publisher

\section{INTRODUCTION}

Estuaries transport nutrients from land to the open sea, and compared with pristine conditions, the nutri-

*E-mail: kni@dmu.dk ent export from land via estuaries to the open sea has increased by at least 1 to 2 orders of magnitude (Howarth et al. 1995, 1996, Conley 2000). Estuarine retention of nitrogen and phosphorus includes 'filtering' of both inorganic and organic components. Estuarine sediments may act as sinks of nitrogen and phos- 
phorus or as temporal sources of nutrient supply, and they may thus significantly alter the quantities of nutrients transported to the open sea.

In general, nitrogen has been considered to be the main limiting nutrient for plant growth and primary production in temperate coastal waters (Ryther \& Dunstan 1971, Granéli et al. 1986, Rosenberg et al. 1990, Borum 1996, Nixon et al. 1996), although the impact of phosphorus limitation has seemingly increased in Danish coastal areas in recent years as result of reduced phosphorus input (Conley 2000). Therefore, the magnitude of nitrogen as well as phosphorus retention may be important for both estuaries and the open sea.

Previous studies have indicated that about $50 \%$ of the nitrogen load is generally retained in estuaries (Seitzinger 1988). In contrast, recent studies have demonstrated variable numbers in estuarine nitrogen retention ranging from low values of 1 to $10 \%$ (Nielsen et al. 1995, Nedwill \& Trimmer 1996, Nowicki et al. 1997, Trimmer et al. 1998, Mortazavi et al. 2000) to moderate values of 10 to $30 \%$ (Nixon et al. 1996, van Beusekom \& de Jonge 1998), or to even higher retention values of $\geq 50 \%$ (Seitzinger 1988, Wulff et al. 1990, Kamp-Nielsen 1992, Boynton et al. 1995).

Retention may be caused by incorporation of nutrients into organisms via sediment deposition as well as permanent removal of nitrogen by bacterial denitrification. Several studies have demonstrated that denitrification rates are strongly influenced by the nitrate concentration in the water column, the oxic conditions in the sediment, input of organic matter, variation in salinity, and the presence of benthic algae and animals (Jenkins \& Kemp 1984, Seitzinger 1990, Rysgaard et al. 1995, 1999, Risgaard-Petersen et al. 1998). Removal of nitrogen by denitrification has been investigated in several Danish estuaries and coastal areas using the isotope-pairing technique, which divides total denitrification into denitrification of $\mathrm{NO}_{3}{ }^{-}$from the water column $\left(\mathrm{D}_{\mathrm{w}}\right)$ and denitrification of $\mathrm{NO}_{3}{ }^{-}$from coupled nitrification-denitrification $\left(D_{n}\right)$ (Nielsen 1992). The average annual denitrification value in these Danish estuaries varies between 14 and $30 \mathrm{~kg} \mathrm{~N} \mathrm{ha}^{-1} \mathrm{yr}^{-1}$ (Christensen et al. 1998), and is thus considerably lower than the 80 to $110 \mathrm{~kg} \mathrm{ha}^{-1} \mathrm{yr}^{-1}$ recently reported from sewage-loaded estuaries (Nowicki et al. 1997).

Intensive investigations are necessary to quantify estuary nutrient retention or denitrification. Therefore, simple models generated on the basis of a limited number of parameters will be useful for estuary management. Nixon et al. (1996) developed empirical models for nitrogen and phosphorus retention as a function of freshwater residence time, the nitrogen model being supported by data from Danish estuaries (Borum 1996, Dalsgaard et al. 2000). Models have also been generated to explain the variation in denitrification. Seit- zinger \& Giblin (1996), for instance, presented rates of coupled nitrification-denitrification with $D_{\mathrm{n}}$ as a linear function of sediment oxygen uptake, and Christensen et al. (1990) proposed a simple diffusion model for estimating $D_{\mathrm{w}}$ from nitrate concentrations in the water column and sediment oxygen uptake.

Until now, only a few studies have determined retention by parallel and truly independent methods using, for instance, both flux measurements and mass balances (Nielsen et al. 1995, Mortazavi et al. 2000), and no studies have been carried out in estuaries along strong gradients of salinity and nutrient concentrations.

The present study aimed at determining nitrogen and phosphorus retention in a eutrophic Danish estuary with significant gradients of nutrients and salinity and at investigating the proportion of denitrification in relation to total nitrogen retention. Further, we investigated whether simple models could substitute complex models or direct measurements. The annual mass balance was estimated using a hydrodynamic model, and denitrification was measured by the isotope-pairing technique. The flux and denitrification measurements were based on incubation of intact sediment cores under in situ conditions. The study was undertaken in Randers Fjord, Denmark, and was part of a monitoring programme conducted by Aarhus County and a research programme headed by the Danish National Environmental Research Institute.

\section{MATERIALS AND METHODS}

Study area. The study was undertaken from November 1994 to December 1995 in the eutrophicated Randers Fjord (Nielsen et al. 1993), a $27 \mathrm{~km}$ shallow estuary situated on the north-east coast of Jutland, Denmark (Fig. 1, Table 1). The catchment area is $3260 \mathrm{~km}^{2}$ of which $64 \%$ is farm land, $19 \%$ forests and other nature reserve areas, $7 \%$ wetlands and lakes, and $10 \%$ villages and cities. The main freshwater input comes from the River Gudenå, which drains $80 \%$ of the catchment area and enters the innermost part of Randers Fjord. A small stream, Alling $\AA$, draining $10 \%$ $\left(340 \mathrm{~km}^{2}\right)$, enters the innermost lateral part joining the main estuary, Grund Fjord. The volume of the estuary is relatively small; approximately $3 \%$ compared with the annual freshwater input from the catchment area. Water exchange is primarily regulated by the freshwater input and the changes in salinity and water level in the Kattegat outside the estuary. The height of the tide ranges from 0.2 to $0.3 \mathrm{~m}$ and is highest in the inner part of the estuary, probably due to the cone-shaped bathymethry of Randers Fjord.

The temperature was generally constant throughout the water column, a thermocline being measured only 
occasionally during summer. Maximum temperatures were 17 to $19^{\circ} \mathrm{C}$ in July and August and minimum temperatures 0 to $3^{\circ} \mathrm{C}$ from December to February. No ice cover was recorded during the investigation.

The uppermost $1 \mathrm{~cm}$ of the sediment consisted of soft mud with high organic content (10 to $14 \%$ ignition loss) in the inner parts of the estuary and fine/ medium-sized silt with low organic content (1 to $2 \%$ ignition loss) in the outer parts (Table 2). The River Gudenå transports freshwater algae and inorganic sediment from upstream lakes to the estuary, and the particles flocculate in the innermost part of the deep navigation channel due to the occurrence of saline water which stimulates particle flocculation. Every $4 \mathrm{yr}$, the Port Authorities dredge 300000 to $400000 \mathrm{~m}^{3}$ of mud and silt from the navigation channel to maintain a depth of $7 \mathrm{~m}$ (Sømod et al. 1999).

Loading and hydrography. Daily freshwater input to the estuary was calculated from the water level using a calibrated water level/water-flow relationship for the River Gudenå and Alling A. Additional input from the

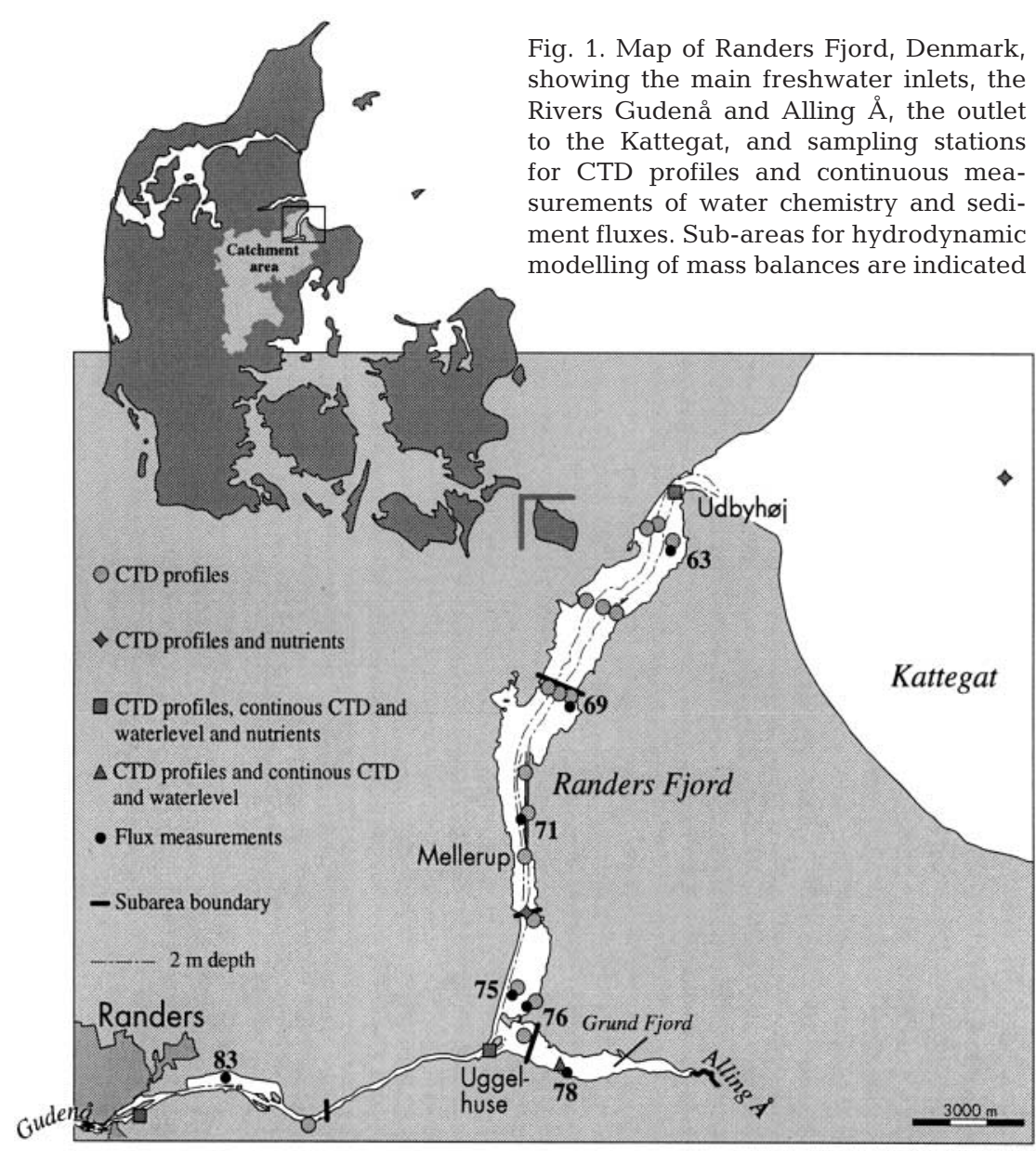

Fig. 1. Map of Randers Fjord, Denmark, showing the main freshwater inlets, the Rivers Gudena and Alling A, the outlet surements of water chemistry and sediment fluxes. Sub-areas for hydrodynamic modelling of mass balances are indicated

Table 1. Characteristics of Randers Fjord and sub-area mass balances of nitrogen and phosphorus estimated by both hydrodynamic modelling and direct measurements

\begin{tabular}{|c|c|c|c|c|c|c|}
\hline \multirow[t]{2}{*}{ Parameter } & \multicolumn{5}{|c|}{ Estuary sub-area } & \multirow[t]{2}{*}{ Total estuary } \\
\hline & Randers & Uggelhuse & Grund & Mellerup & Udbyhøj & \\
\hline Area $\left(\mathrm{km}^{2}\right)$ & 1.4 & 3.0 & 1.7 & 5.7 & 7.5 & 19.4 \\
\hline Volume $\left(106 \mathrm{~m}^{3}\right)$ & 4.1 & 5.9 & 0.9 & 9.4 & 11.7 & 31.9 \\
\hline Mean depth (m) & 2.9 & 2.0 & 0.5 & 1.6 & 1.6 & 1.6 \\
\hline Residence time $(50 \%)$ of freshwater $(\mathrm{d})$ & $0.5-1.5$ & $0.5-1.5$ & $0.8-2.3$ & $2.5-7.0$ & $2.5-7.0$ & $3.0-8.0$ \\
\hline Sediment-flux stations & $83,75^{a}$ & $78,76,75^{\mathrm{a}}$ & 78 & 69,71 & 69,63 & \\
\hline \multicolumn{7}{|l|}{ Nitrogen (tonnes 15 Jan-11 Dec 1995) } \\
\hline Denitrification & 19.7 & 46.7 & 26.0 & 94.0 & 94.4 & 280.7 \\
\hline Flux of nitrate & -11.6 & -23.0 & -9.2 & -47.6 & -96.0 & -187.4 \\
\hline Flux of ammonia & 3.4 & 10.6 & 1.0 & 17.9 & 32.4 & 65.3 \\
\hline Model-estimated retention of total nitrogen & 66.4 & 99.7 & 59.5 & 150.6 & 174.0 & 550.3 \\
\hline Model-estimated release of total nitrogen & 7.8 & 17.5 & 0.3 & 21.9 & 41.1 & 88.6 \\
\hline Model-estimated net-balance of total nitrogen & 58.6 & 82.1 & 59.2 & 128.8 & 132.9 & 461.7 \\
\hline \multicolumn{7}{|l|}{ Phosphorus (tonnes 15 Jan-11 Dec 1995) } \\
\hline Flux of inorganic phosphorus & 0.7 & 9.5 & 5.4 & 13.5 & 0.6 & 29.7 \\
\hline Model-estimated retention of total phosphorus & 8.2 & 7.4 & 3.4 & 10.5 & 9.0 & 38.6 \\
\hline Model-estimated release of total phosphorus & 1.1 & 6.4 & 0.7 & 9.7 & 6.1 & 24.0 \\
\hline Model-estimated net-balance of total phosphorus & 7.1 & 1.0 & 2.7 & 0.8 & 2.9 & 14.5 \\
\hline Flux of oxygen (tonnes 15 Jan-11 Dec 1993) & -326.0 & -684.3 & -347.5 & -1112.6 & -848.7 & -3319.1 \\
\hline
\end{tabular}


Table 2. Range of salinity, nutrient concentrations in surface and bottom water, and organic content at 5 stations in Randers Fjord and the Kattegat

\begin{tabular}{|c|c|c|c|c|c|c|c|c|}
\hline \multirow[t]{2}{*}{ Station } & \multirow{2}{*}{$\begin{array}{l}\text { Depth } \\
(\mathrm{m})\end{array}$} & \multicolumn{3}{|c|}{ Surface-water parameter range } & \multicolumn{3}{|c|}{ Bottom-water parameter range } & \multirow{2}{*}{$\begin{array}{l}\text { Sediment organic } \\
\text { content } \\
(\% \text { dry wt) }\end{array}$} \\
\hline & & $\begin{array}{l}\text { Salinity } \\
(\%)\end{array}$ & $\begin{array}{c}\text { Nitrate } \\
\left(\mathrm{mmol} \mathrm{l}^{-1}\right)\end{array}$ & $\begin{array}{l}\text { Phosphorus } \\
\left(\mathrm{mmol} \mathrm{l}^{-1}\right)\end{array}$ & $\begin{array}{l}\text { Salinity } \\
(\%)\end{array}$ & $\begin{array}{c}\text { Nitrate } \\
\left(\mathrm{mmol} \mathrm{l}^{-1}\right)\end{array}$ & $\begin{array}{l}\text { Phosphorus } \\
\left(\mathrm{mmol} \mathrm{l}^{-1}\right)\end{array}$ & \\
\hline Randers & 6 & $0-13$ & $15-65$ & $0.15-2.00$ & $0-22$ & $6-60$ & $0.28-3.00$ & $10-14$ \\
\hline Uggelhuse & 7 & $0-16$ & $10-60$ & $0.22-2.40$ & $0-27$ & $3-35$ & $0.03-3.20$ & $7-15$ \\
\hline Grund Fjord & 1 & $0-28$ & - & - & - & - & - & $3-8$ \\
\hline Udbyhøj & 10 & $3-29$ & $0.1-50$ & $0.06-2.00$ & $3-30$ & $0.08-24$ & $0.03-1.00$ & $1-2$ \\
\hline Kattegat & 9 & $15-29$ & $0.04-14$ & $0.03-0.90$ & $21-30$ & $0.04-2$ & $0.03-0.75$ & $0.5-1.5$ \\
\hline
\end{tabular}

remaining $10 \%$ of the catchment area was estimated on the basis of the input from the Alling $\AA$ catchment using the nitrogen and phosphorus input per $\mathrm{km}^{2}$. Chemical analysis of the stream water was performed 25 and 18 times during the study period in the River Gudenå and Alling $\AA$, respectively. Nitrogen and phosphorus inputs were calculated from the product of daily values of nitrogen/phosphorus concentrations. The daily values of nitrogen/phosphorus concentrations can be estimated by linear interpolation between measured nitrogen/phosphorus concentrations. Furthermore, stream water in the River Gudenå was sampled by an automatic sampler (ISCO 3200) every $4 \mathrm{~h}$ throughout the investigation period to catch spikes of particulate phosphorus during high water discharge. Direct outlets of wastewater from industry and sewage treatment plants were measured by wastewater sampling. These nitrogen and phosphorus sources were of minor importance compared with the total loading, accounting for only 1 and $3 \%$, respectively.

Salinity and temperature profiles were measured with a CTD probe every 2 wk at 23 permanent monitoring stations. Water was sampled from the water column from a boat at 5 monitoring stations (Fig. 1) using a Niskin water sampler. Bi-weekly samples from the top layer $(0.5 \mathrm{~m})$ and bottom layer $(1.0 \mathrm{~m}$ above the sea bed) were analysed for total nitrogen (dissolved and particulate), nitrate, ammonium, total phosphorus (dissolved and particulate) and phosphate.

The water samples were then stored in darkness at in situ temperature and analyses were performed within $3 \mathrm{~h}$ employing conventional methods (Greensberg 1992). The samples from the automatic sampler were stored in darkness at in situ temperature for up to $5 \mathrm{~d}$ and only analysed for total nitrogen and total phosphorus. These samples of total nitrogen and phosphorus compared well with the samples stored for only $3 \mathrm{~h}$. During the study period, water level, salinity and temperature were recorded automatically every $15 \mathrm{~min}$ at 4 stations situated in the inner, middle and outer part of the estuary and in Grund Fjord (Fig. 1). Except in the shallow Grund Fjord, salinity and temperature were measured at 3 depths: surface $(0.8 \mathrm{~m})$, middle (3.6 to $4.8 \mathrm{~m}$ ) and above the sea floor (6.2 to $9.6 \mathrm{~m})$. An intensive monitoring campaign was conducted from 11 November to 8 December 1995, when continuous measurements of current speed and current direction were made at the mouth of the estuary.

Sediment and water sampling. In situ water and intact sediment cores were sampled at the 7 stations (Fig. 1) 9 times at 25 to 41 d intervals from February to December 1995. On every sampling occasion, 10 intact sediment cores were collected at each station in Plexiglas tubes (height: $30 \mathrm{~cm}$, inner diameter $5.2 \mathrm{~cm}$ ) by SCUBA divers. Bottom water for incubation and analysis of in situ nutrient and $\mathrm{O}_{2}$ concentrations was sampled with a 51 Niskin sampler. The incubation samples were stored in $30 \mathrm{l}$ polyethylene jars, while samples for $\mathrm{O}_{2}$ determination were transferred to $12 \mathrm{ml}$ glass vials (Exetainer $^{\circledR}$, Labco, High Wycombe, UK) in the field, Winkler reagents being added immediately (Strickland \& Parsons 1972). Samples for nutrient analysis were filtered (Whatmann GF/C glass-fibre), transferred to $10 \mathrm{ml}$ polyethylene vials, and kept cold and dark until return to the laboratory ( 4 to $6 \mathrm{~h}$ ) where they were frozen $\left(-18^{\circ} \mathrm{C}\right)$ for later analysis.

In the laboratory, the height of the sediment cores in the Plexiglas tubes was adjusted to $11 \mathrm{~cm}$. Thereafter, the tubes were placed in open tanks with air-saturated bottom water held at in situ temperature. A small, Teflon-coated, rotating $(60 \mathrm{rpm})$ magnet $(0.5 \times 3 \mathrm{~cm})$, mounted inside the tubes, kept the water column above the sediment mixed. The cores were pre-incubated for $24 \mathrm{~h}$ before further processing.

Flux and denitrification measurements. Denitrification activity and fluxes of nutrients $\left(\mathrm{NO}_{3}{ }^{-}+\mathrm{NO}_{2}{ }^{-}, \mathrm{NH}_{4}{ }^{+}\right.$ and $\left.\mathrm{PO}_{4}{ }^{3-}\right)$ and $\mathrm{O}_{2}$ across the sediment water interface were measured in both the light $\left(100 \mu \mathrm{mol}\right.$ photons $\mathrm{m}^{-2}$ $\mathrm{s}^{-1}$ provided by $500 \mathrm{~W}$ Halogen lamps) and the dark. The measurements were performed in 2 sessions. First, flux rates were measured and then, following an equilibrium period of $12 \mathrm{~h}$, denitrification activity was measured on the same set of cores. For all incubations, 4 cores were selected for light incubations and 4 cores 
for dark incubations from each station. Tanks with cores selected for dark incubations were covered with opaque lids, while tanks with cores selected for light incubations were left exposed.

Flux measurements were initiated by closing the Plexiglas tubes with transparent lids. The incubation time was 1 to $20 \mathrm{~h}$ depending on the season, and within that period the change in $\mathrm{O}_{2}$ did not exceed $20 \%$ of the initial concentration. Water samples for nutrient and $\mathrm{O}_{2}$ analyses were collected from the water column within the tubes using a glass syringe immediately prior to sealing of the tubes and immediately after completion of the incubations. Samples for $\mathrm{O}_{2}$ determination were analysed within $12 \mathrm{~h}$ by the Winkler titration technique, while $\mathrm{GF} / \mathrm{C}$ filtered samples for $\mathrm{NO}_{3}{ }^{-}$, $\mathrm{NH}_{4}{ }^{+}$and $\mathrm{PO}_{4}{ }^{3-}$ were frozen $\left(-18^{\circ} \mathrm{C}\right)$ for later analysis. $\mathrm{NO}_{3}{ }^{-}$and $\mathrm{NO}_{2}{ }^{-}$were determined using standard methods (Grasshoff et al. 1983) on a flow-injection analyser (Perstop Analytical, Environmental Wilsonville, Oregon, USA). Ammonium was analysed colorimetrically as described by Bower \& Holm-Hansen (1980), and $\mathrm{PO}_{4}{ }^{3-}$ was determined by a standard colorimetric method developed by Grasshoff et al. (1983). Hourlybased flux rates were determined from changes over time in the concentration of relevant species in the water column.

Denitrification was measured using ${ }^{15} \mathrm{~N}$-methodology (Risgaard-Petersen \& Rysgaard 1995). ${ }^{15} \mathrm{~N}$-labelled $\mathrm{NO}_{3}{ }^{-}$was added to the water in the reservoirs, resulting in an enrichment of the $\mathrm{NO}_{3}{ }^{-}$pool between 16 and $72{ }^{15} \mathrm{~N}$ at. $\%$, depending on the in situ $\mathrm{NO}_{3}{ }^{-}$concentration. Following an equilibrium period of approximately $15 \mathrm{~min}$, the Plexiglas tubes were sealed and incubation was initiated. After 1 to $20 \mathrm{~h}$, samples of the water column and sediment porewater were collected for determination of the ${ }^{15} \mathrm{~N}_{2}\left({ }^{29} \mathrm{~N}_{2},{ }^{30} \mathrm{~N}_{2}\right)$ concentration and ${ }^{15} \mathrm{~N}$ enrichment of the $\mathrm{NO}_{3}{ }^{-}$pool. Samples for gas analysis were transferred to $12 \mathrm{ml}$ glass vials (Exetainers ${ }^{\circledR}$, Labco, High Wycombe, UK) and preserved with an additional $250 \mu \mathrm{l}$ of $7 \mathrm{M} \mathrm{ZnCl}_{2}$, while samples for ${ }^{15} \mathrm{NO}_{3}{ }^{-}$ analysis were frozen in $10 \mathrm{ml}$ polyethylene vials.

Concentrations of ${ }^{29} \mathrm{~N}_{2}$ and ${ }^{30} \mathrm{~N}_{2}$ in the water and slurry samples were determined on a gas chromatograph connected with a triple-collector isotope-ratio mass spectrometer (Robo-Prep-G in line with TracerMass, Europe Scientific, Crewe, UK), as described by Risgaard-Petersen \& Rysgaard (1995). The ${ }^{15} \mathrm{~N}$ at. \% of $\mathrm{NO}_{3}^{-}$was measured by mass spectrometry after biological reduction to $\mathrm{N}_{2}$ (Risgaard-Petersen et al. 1993).

In situ denitrification activity (i.e. denitrification of unlabelled $\mathrm{NO}_{3}{ }^{-}$) was calculated using the principle of the isotope-pairing technique (Nielsen 1992). Before applying this approach, we verified the fundamental assumptions of the technique, i.e. first-order dependency of denitrification with respect to $\mathrm{NO}_{3}{ }^{-}$concen- tration in the water column and uniform mixing of ${ }^{14} \mathrm{NO}_{3}{ }^{-}$and ${ }^{15} \mathrm{NO}_{3}{ }^{-}$in the denitrification zone (Nielsen 1992). This verification analysis was performed with intact cores from Station $83(\mathrm{n}=4 \times 3)$ that were incubated as described above with 4 different ${ }^{15} \mathrm{NO}_{3}{ }^{-}$concentrations in the incubation media $(25,50,80$ and $160 \mu \mathrm{M}$, data not shown).

Diurnal flux and denitrification rates were calculated from rates obtained in the light multiplied the day length plus the rates obtained in darkness multiplied the length of the dark period (i.e. $24 \mathrm{~h}$ day length). Day length was defined as the average time from sunrise to sunset for the actual month. For further details see Rysgaard et al. (1995).

Total fluxes of $\mathrm{O}_{2}, \mathrm{NH}_{4}{ }^{+}, \mathrm{NO}_{3}{ }^{-}, \mathrm{PO}_{4}{ }^{3-}$ and denitrification were estimated for each sub-area by multiplying the measured flux rates for each time interval with the extent of the sub-areas. Mean flux rates were used for sub-areas with more than 1 sediment station. For the inner sub-areas, Randers and Uggelhuse, denitrification was estimated separately for the navigation channel and shallow areas, and total denitrification was calculated according to the extent $\left(\mathrm{km}^{2}\right)$ of the navigation channel and shallow areas, respectively (Table 1).

Numerical modelling. Model description: Numerical, hydrodynamic modelling of Randers Fjord was made using a 2-layer, hydrodynamic channel modelthe MIKE 12 model system (Ecological Modeling Center 1992, Bach \& Jensen 1994; available at: www. dhisoftware.com/mike11/Description/mike_12.htm). The model solves the conservation equation for mass and momentum and consists of a hydrodynamic sub-model (HD) and an advection-dispersion sub-model (AD). The HD sub-model simulates the water level, current velocity and salinity at each time step and for each channel segment along the model string in the upper and lower layers. The momentum equation includes the effect of wind friction, bed friction and entrainment. The model assumed that the 2 layers were vertically homogenous and separated by a sharp pycnocline. However, the field measurements did not fully support the model results (see 'Hydrography, load and water residence time').

Simultaneously with the HD calculations, the AD model simulates the transport and concentrations of dissolved or suspended matter by solving the 1-dimensional advection-dispersion equation. In the AD submodel, the dispersion coefficient is a measure of the total longitudinal water exchange not derived from advection. The vertical water exchange between the upper and the lower layer, the mixing, is described by a '2-way' entrainment function. Variations in bed topography, turbulence generated by bed or wind friction and the presence of density (salinity) gradients may all influence the magnitude of the dispersion coefficient 
Table 3. Parameters for calibrating the MIKE12 model along the model string: wind-stress factor, Chezy number and dispersion coefficient. Station distance: distance from the head of the estuary

\begin{tabular}{|lcccc|}
\hline \multirow{2}{*}{ Location } & \multicolumn{5}{c|}{$\begin{array}{c}\text { Model string } \\
\end{array}$} & $\begin{array}{c}\text { Station } \\
\text { distance }(\mathrm{km})\end{array}$ & $\begin{array}{c}\text { Wind-stress } \\
\text { factor }\end{array}$ & $\begin{array}{c}\text { Chezy } \\
\text { no. }\end{array}$ & $\begin{array}{c}\text { Dispersion coefficient } \\
\text { Top layer Bottom layer }\end{array}$ \\
\hline Randers & $0.0-10.8$ & 0.6 & 100 & 50 \\
& $10.8-12.0$ & 0.6 & 150 & 100 \\
& $12.0-13.0$ & 0.7 & 150 & 100 \\
& $13.0-14.4$ & 0.6 & 150 & 100 \\
& $14.4-20.0$ & 0.2 & 150 & 100 \\
Grund Fjord & $20.0-27.5$ & 0.2 & 150 & 100 \\
Grund Fjord (south) & $0.0-5.0$ & 0.6 & 25 & 10 \\
Navigation channel & $0.0-0.5$ & 0.6 & 50 & 10 \\
Nordhavn & $0.0-3.0$ & 0.4 & 100 & 50 \\
Kattegat & $0.0-2.0$ & 0.2 & 100 & 10 \\
Dronningborg & $0.0-5.0$ & 0.1 & 50 & 200 \\
Gudenaa & $0.0-2.1$ & 0.6 & 100 & 10 \\
& $0.0-20.0$ & 1.0 & 10 & 2 \\
\hline
\end{tabular}

during the first time period (30 d) and verified over the next 8 time periods (375 d), with good correspondence between measured and simulated water levels and salinities $\left(r^{2}=0.97\right.$ and $\left.r^{2}=0.84\right)$.

Estimation of freshwater residence time: Residence time was defined as the time taken for $50 \%$ of a dissolved substance to leave the area. The freshwater residence time was estimated from simulations of the calibrated MIKE 12 model, involving the initial 'discharge' of a pulse of tracer into the River Gudenå and Alling Å. The propagation of this pulse through the estuary to the Kattegat was followed by calculating the mass transport at each time step through each section. Using this technique, the residence time was calculated for 8 different typical peri-

and the entrainment coefficient, and in Randers Fjord the dispersion coefficient may therefore be subject to considerable temporal and spatial variation (Table 3).

Model set-up: The MIKE 12 model of Randers Fjord was set up on the basis of bathymetry in 37 cross-sections. The model was extended $4 \mathrm{~km}$ outside the estuary to obtain homogeneous salinity boundary conditions at the upward boundary towards the Kattegat. According to the model, $80 \%$ of the freshwater from the catchment area was discharged into the inner part of Randers Fjord, 10\% into the inner part of Grund Fjord, and the remainder into the outer fjord (Fig. 1). Precipitation and evaporation were included in the model as independent sources. All freshwater sources were based on daily average values (Water Consult 1997). The freshwater discharge from the River Gudenå into Randers Fjord and the water level in the Kattegat outside the estuary had major impact on the estuarine water flow. The effect of wind action was also included in the model using 3-hourly values of wind speed and direction.

Model calibration: The hydrodynamic model of the estuary was calibrated on the basis of all data on freshwater discharge, water level, pycnocline level and salinity. As bed resistance, a fixed Chezy number $\left(30 \mathrm{~m}^{1 / 2} \mathrm{~s}^{-1}\right)$ was used for calibration of the HD submodel, while the AD model was calibrated by varying the dispersion coefficient, the wind-friction factor and the entrainment model factors. Dispersion coefficients were specified individually for each of 8 sub-areas representing each of the areas up- and downstream of the fixed stations. The dispersion coefficient ranged from 10 to 150 and 2 to $200 \mathrm{~m}^{2} \mathrm{~s}^{-1}$ in the upper and lower layer, respectively (Table 3 ). The model was calibrated ods varying as to freshwater discharge (Water Consult 1997).

Mass balance: Nitrogen and phosphorus concentrations were simulated with the calibrated MIKE 12 AD model for all 9 time periods. The dominant source of nutrients was the River Gudenå. The simulation was carried out by discharging the freshwater with varying concentrations of nitrogen and phosphorus, specified for each source.

Retention was included in these simulations by adjusting the decay coefficient related to the concentrations of nitrogen or phosphorus. For each simulation period, the decay coefficient was initially set to zero. If necessary, the decay coefficient was adjusted until the simulated values fitted the nitrogen or phosphorus concentrations measured in the estuary. The simulation providing the best fit was then used to calculate the mass balances. The mass balances provide information on nutrient transport into and out of the estuary for each period and for each of the 5 separate subareas (Fig. 1) as well as on sediment storage, retention and release. The same method has been used to estimate mass balances for other estuaries (Nielsen et al. 1995).

\section{RESULTS}

\section{Hydrography, load and water residence time}

The salinity in the inner part of the estuary was influenced by inflow of freshwater that formed a low saline upper layer flowing towards the mouth. At the mouth of the estuary, highly saline water was transported as a 
bottom layer into the navigation channel as a consequence of density differences, the result being a sharp pycnocline separating the 2 layers. The pycnoline was registered during approximately $90 \%$ and almost $100 \%$ of the year in the inner and outer part of the estuary, respectively. Pycnocline depth in the navigation channel was typically $4 \mathrm{~m}$ in the inner part and $2 \mathrm{~m}$ in the outer part. Salinity was highly variable, ranging from $0-13$ to $3-29 \%$ in the surface layer and from $0-22$ to $3-30 \%$ in the bottom layer at the inner and outer station, respectively (Table 2). Mean salinity of the surface water ranged from 0.2 to $12.7 \%$ and that of the bottom layer from 12.2 to $22.2 \%$ at the same stations. Mixing between the 2 layers along the estuary was driven by wind and current. The salinity in the inner third of the estuary was highly variable, ranging from freshwater in the whole water column to $0.8 \mathrm{~m}$ at pycnocline depth.

The nitrogen load was estimated to $4560 \mathrm{t} \mathrm{N}$ during the investigation period, and monthly loading ranged from 130 to $1150 \mathrm{t} \mathrm{N}$, with maximum values in January to March. The majority of the freshwater nitrogen input was inorganic nitrogen, accounting for 50 to $80 \%$ of the input. Phosphorus input from freshwater was $161 \mathrm{t} \mathrm{P}$ during the investigation period, and monthly values were high, 20 to $30 \mathrm{t} \mathrm{P}$, from January to April. Particulate phosphorus accounted for 40 to $90 \%$ of the freshwater input with maximum values from April to July (Fig. 2).

The estimated freshwater residence time in Randers Fjord, defined as the time period for $50 \%$ exchange of freshwater, was 3 to $8 \mathrm{~d}$ throughout the year, with a mean freshwater residence time of $6 \mathrm{~d}$ for the entire estuary. The freshwater residence time was extremely low $(0.5$ to $1.5 \mathrm{~d})$ in the inner part of Randers Fjord (Table 1). The estimated residence time of the estuarine water (exchange of $95 \%$ of the water) was 5 to $22 \mathrm{~d}$, with a mean residence time for the estuarine water of $13 \mathrm{~d}$. The lowest residence times occurred during periods of high freshwater input.

\section{Denitrification, $\mathrm{NO}_{3}{ }^{-}$and $\mathrm{NH}_{4}{ }^{+}$fluxes-direct measurements}

There was no significant spatial variation in average annual denitrification activity from the head of the estuary to the mouth (Fig. 3), despite significant gradients in both bottom-water salinity and $\mathrm{NO}_{3}{ }^{-}$concentrations (Table 2). Denitrification showed significant seasonal variation at all monitoring stations except the outer one (Stn 63) (Fig. 4). Different seasonal patterns in activity were, however, observed: At Stn 83, the activity peaked in August and September, while at Stn 75 denitrification peaked in February and March. Denitrification rates for the entire estuary were highest in

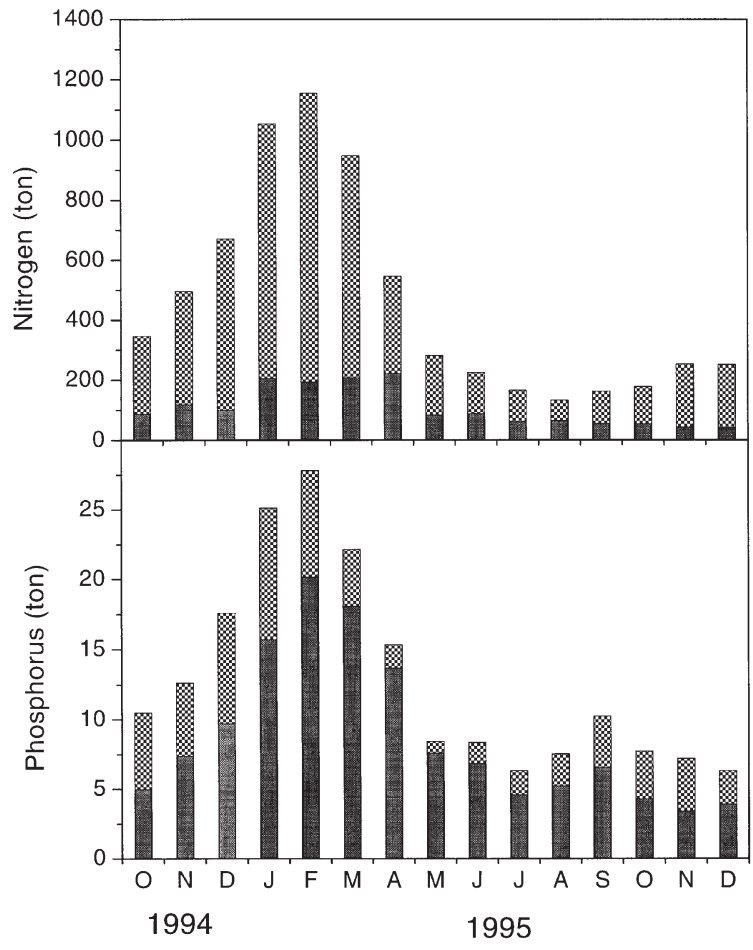

Fig. 2. Freshwater input of nitrogen and phosphorus in 1994 and 1995 to Randers Fjord. Grey and dark grey bars represent inorganic and particulate nitrogen or phosphorus, respectively

February and March and June and July, amounting to 4.0 and $5.8 \mathrm{mmol} \mathrm{N} \mathrm{m}^{-2} \mathrm{~d}^{-1}$, respectively. Outside these periods, denitrification rates were more or less constant at $2 \mathrm{mmol} \mathrm{N} \mathrm{m}{ }^{-2} \mathrm{~d}^{-1}$ except in November (Fig. 5). Throughout the season, both the $\mathrm{NO}_{3}{ }^{-}$in the water column and $\mathrm{NO}_{3}{ }^{-}$produced via sedimentary nitrification

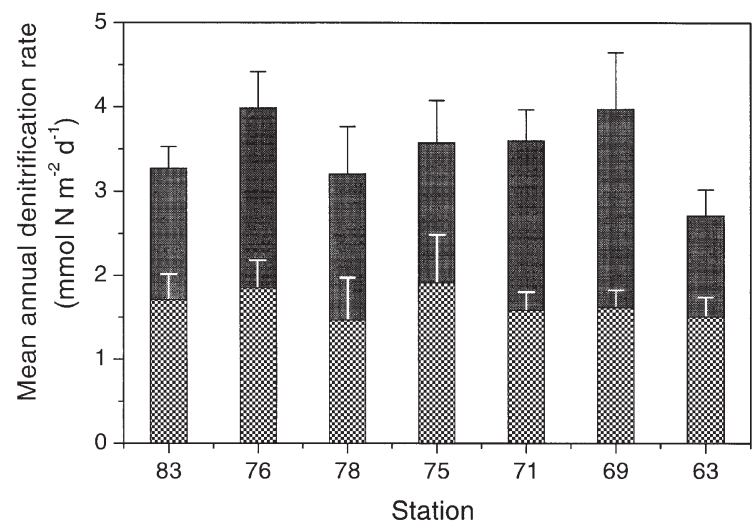

Fig. 3. Mean denitrification rate (averages for 7 stations) in the bottom water from the head to the mouth of Randers Fjord, 1995. Dark grey and grey bars represent $D_{\mathrm{n}}$ (coupled nitrification-denitrification) and $D_{\mathrm{w}}$ (denitrification from the water column), respectively. Error bars SE $(n=5)$ 


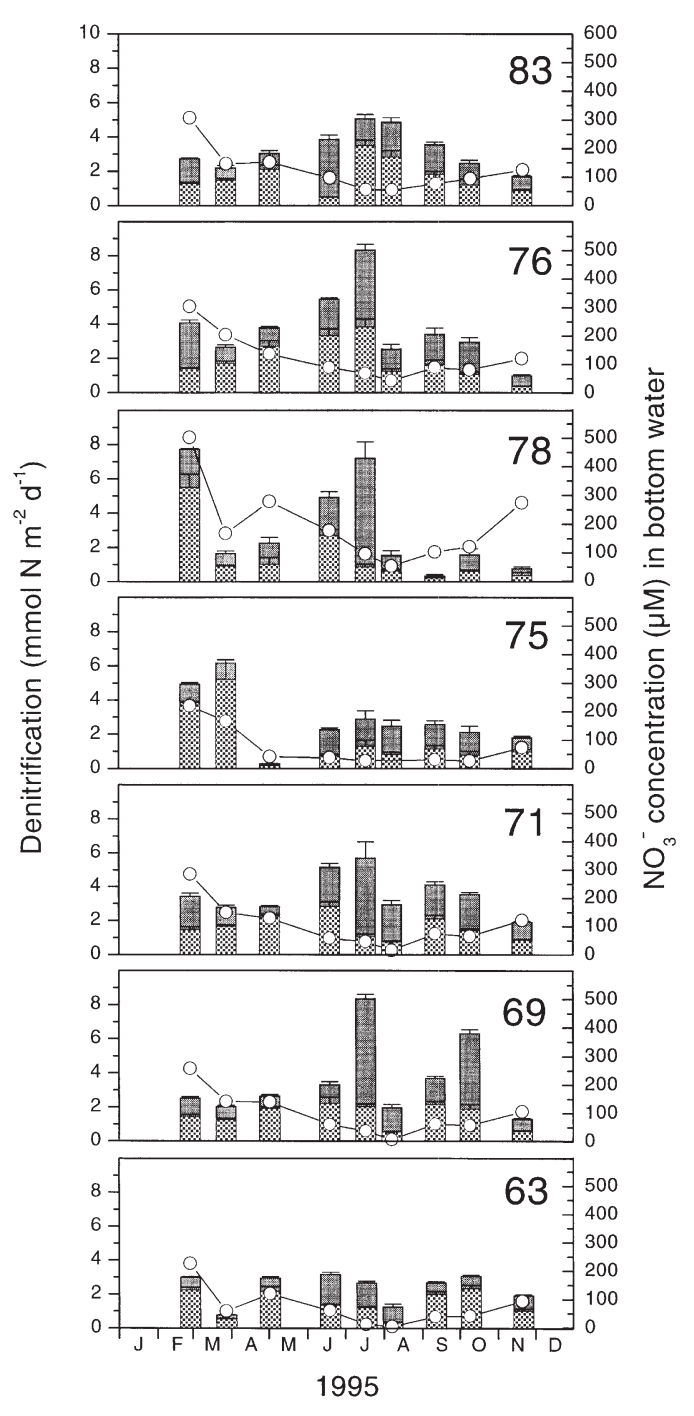

Fig. 4. Annual denitrification at 7 stations in Randers Fjord. Dark grey and grey bars: $D_{\mathrm{n}}$ and $D_{\mathrm{w}}$, respectively; $(\mathrm{O})$ in situ $\mathrm{NO}_{3}{ }^{-}$concentrations of the bottom water. Error bars $=\mathrm{SE}(\mathrm{n}=5)$

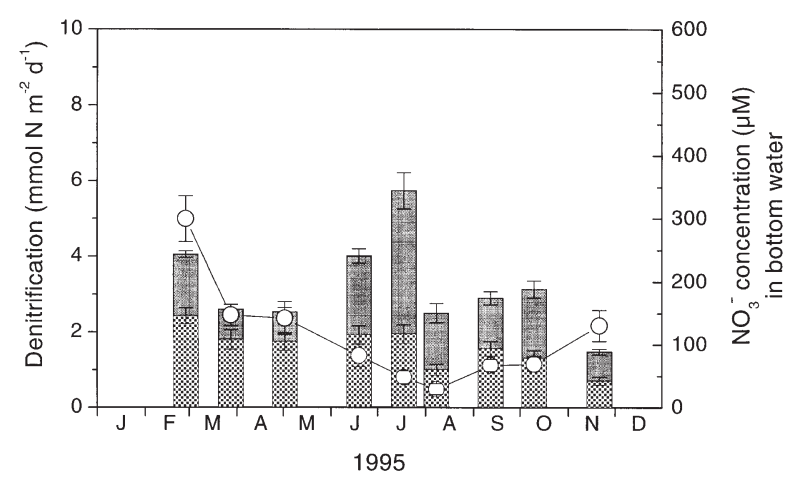

Fig. 5. Total denitrification, $D_{\mathrm{w}}$ and $D_{\mathrm{n}}$ and nitrate concentrations in the bottom water for 7 stations in Randers Fjord 1995. Dark grey and grey bars: $D_{\mathrm{n}}$ and $D_{\mathrm{w}}$ respectively; (O) in situ $\mathrm{NO}_{3}{ }^{-}$concentrations of the bottom water. Error bars $=\mathrm{SE}(\mathrm{n}=5)$ were important sources of $\mathrm{NO}_{3}{ }^{-}$for denitrification. From March to May, approximately 60 to $70 \%$ of the total denitrification in Randers Fjord was based on $\mathrm{NO}_{3}{ }^{-}$supplied from the water column. During June to August, denitrification was mainly based on $\mathrm{NO}_{3}{ }^{-}$produced in the sediment via nitrification (60 to $67 \%$ ). Thereafter, both sources contributed equally to the process (Figs 4 \& 5). The average annual denitrification rate for the entire estuary was estimated at $140 \mathrm{~kg} \mathrm{~N}$ $\mathrm{ha}^{-1} \mathrm{yr}^{-1}$, corresponding to a removal of $280 \mathrm{t} \mathrm{N} \mathrm{yr}^{-1}$ for the entire estuary. Thus, denitrification removed approximately $6 \%$ of the freshwater nitrogen input.

Sediment uptake of nitrate from the water column was observed throughout the year, except for short periods in July to September at individual stations. Mean values of up to $3.7 \mathrm{mmol} \mathrm{N} \mathrm{m}^{-2} \mathrm{~d}^{-1}$ for the entire estuary were measured in March and April (Fig. 6), with local nitrate uptake values as high as $9.3 \mathrm{mmol}$ $\mathrm{m}^{-2} \mathrm{~d}^{-1}$. Low nitrate uptake $\left(0.1\right.$ to $\left.0.7 \mathrm{mmol} \mathrm{N} \mathrm{m} \mathrm{m}^{-2} \mathrm{~d}^{-1}\right)$ ocurred in July and August. During the same period, ammonia was released from the sediment to the water column. Efflux of ammonia was found in spring and summer, when mineralization was stimulated by high input of organic matter to the sediment. The mean efflux for the entire estuary was approximately 1.0 to $2.5 \mathrm{mmol} \mathrm{N} \mathrm{m}^{-2} \mathrm{~d}^{-1}$ during summer and autumn, while the winter uptake was locally below $1 \mathrm{mmol}$ $\mathrm{N} \mathrm{m}^{-2} \mathrm{~d}^{-1}$.

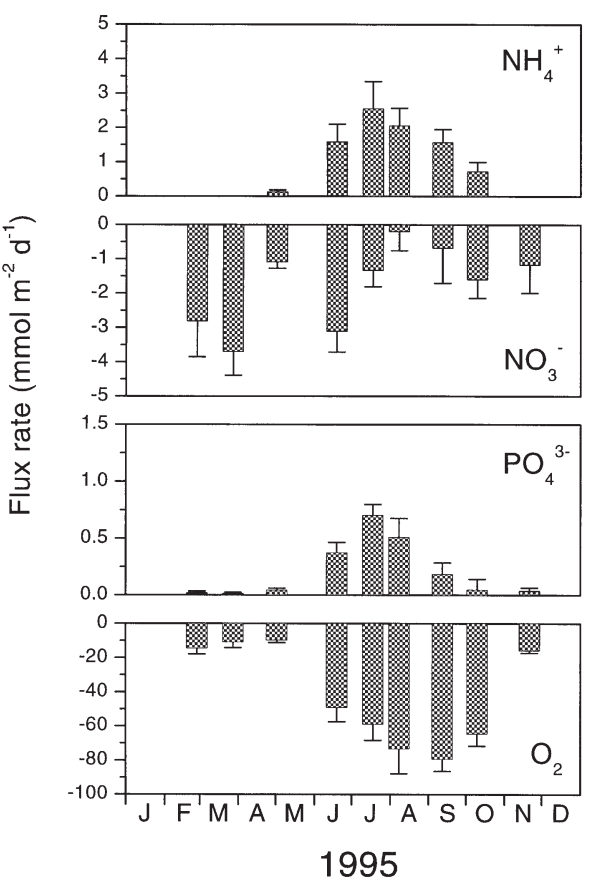

Fig. 6. Mean fluxes of nitrate, ammonia, inorganic phosphorus and oxygen across the water-sediment interface in 1995 in Randers Fjord. Error bars $=\mathrm{SE}(\mathrm{n}=5)$ 
Fig. 7. Nitrogen mass balance (tonnes) for Randers Fjord from 15 January to 11 December 1995 showing sources and sinks. Nitrogen retention was calculated on the basis of the hydrodynamic model

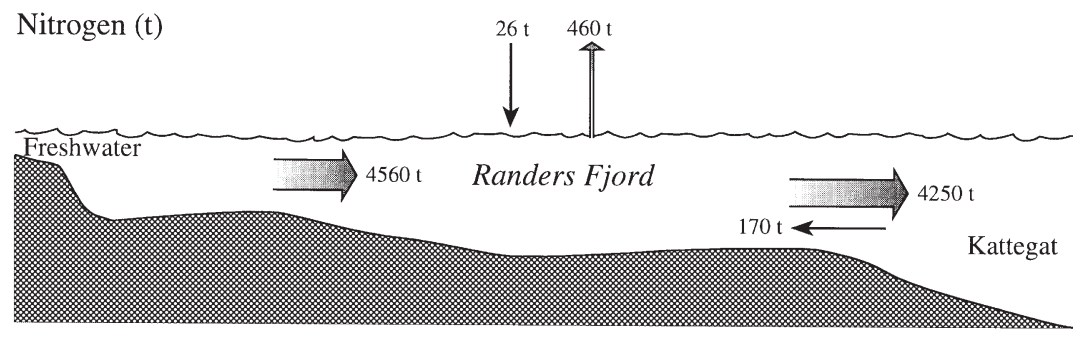

On an annual scale, $187 \mathrm{t} \mathrm{NO}_{3}^{-}-\mathrm{N}$ were removed from the water column within the estuary and transferred to the sediment system, while $65 \mathrm{t} \mathrm{NH}_{4}{ }^{+}-\mathrm{N}$ were released from the sediment to the bottom water (Table 1). Thus, the sediment in Randers Fjord acted as net sink for dissolved inorganic nitrogen during the investigation period.

\section{Nitrogen retention estimated by hydrodynamic modelling}

During the modelling period (15 January to $11 \mathrm{De}-$ cember 1995), nitrogen input to the estuary was $4560 \mathrm{t}$ $\mathrm{N} \mathrm{yr}^{-1}$ and net output to the Kattegat amounted to $4250 \mathrm{t} \mathrm{N} \mathrm{yr}^{-1}$, while the inaccuracy of the total mass balance model amounted to approximately $50 \mathrm{t} \mathrm{N} \mathrm{yr}^{-1}$. Input from atmospheric deposition was only $26 \mathrm{t} \mathrm{N} \mathrm{yr}{ }^{-1}$. Model-estimated retention was 460 t N. Nitrogen retention from mass balances was approximately $10 \%$ of the freshwater input (Fig. 7). Because of the recorded net transport of saline water from the Kattegat to the estuary, the net input of nitrogen was estimated for the bottom layer. However, the nitrogen input from the bottom layer was insignificant $\left(0.1\right.$ to $\left.0.9 \mathrm{t} \mathrm{N} \mathrm{d}^{-1}\right)$ for the total mass balance of the estuary (Table 4).

Nitrogen net retention was highest in the inner subarea (Randers), amounting to $58.6 \mathrm{t} \mathrm{N}$, or $42 \mathrm{t} \mathrm{N} \mathrm{km}^{-2}$, while net nitrogen retention was 18 to $23 \mathrm{t} \mathrm{N} \mathrm{km}^{-2}$ in outer sub-areas. Nitrogen release was estimated for all sub-areas. In Grund Fjord it was found to be negligible $(0.3 \mathrm{t} \mathrm{N})$ during the entire investigation period (Table 1).

Mass balances based on the hydrodynamic MIKE 12 model revealed high nitrogen retention in November 1994 during calibration, net retention being $6.5 \mathrm{t} \mathrm{N} \mathrm{d}^{-1}$ or $40 \%$ of the freshwater input (Table 4). Maximum retention was estimated in November 1994, a possible explanation being sedimentation of dying freshwater organic matter transported to Randers Fjord by a very high freshwater discharge (Sømod et al. 1999).

No nitrogen retention was found in winter, when the freshwater input was balanced by transport out of the estuary. During spring (March to May), net retention amounted to 1.3 to $5.9 \mathrm{t} \mathrm{N} \mathrm{d}^{-1}$, corresponding to 12 to $22 \%$ of the freshwater input. The high nitrogen retention resulted from high freshwater discharge with increased concentrations of nitrate and organic matter prior to the period of high nitrogen retention. Nitrogen retention was low ( 1 to $2 \mathrm{t} \mathrm{N} \mathrm{d}^{-1}$ ) during summer. In contrast to the measured denitrification rates (Fig. 8), the model recorded no retention in autumn 1995.

\section{Phosphorus and oxygen exchange- direct measurements}

Total annual net efflux of phosphorus was estimated at $29.7 \mathrm{t} \mathrm{P}$ on the basis of flux rates. High efflux values of 9.5 and $13.5 \mathrm{t}$, respectively, the middle of Randers

Table 4. Nitrogen mass balance $\left(\mathrm{t} \mathrm{d}^{-1}\right)$ estimated by hydrodynamic modelling for each of the 9 simulation periods from 1 November 1994 to 11 December 1995. 'Difference' expresses inaccuracy of the model estimation

\begin{tabular}{|c|c|c|c|c|c|c|c|c|c|}
\hline Parameter & $\begin{array}{c}1 \\
1 / 11 / 94 \text { to } \\
1 / 12 / 94\end{array}$ & $\begin{array}{c}2 \\
1 / 12 / 94 \text { to } \\
15 / 1 / 95\end{array}$ & $\begin{array}{c}3 \\
15 / 1 / 95 \text { to } \\
1 / 3 / 95\end{array}$ & $\begin{array}{c}4 \\
1 / 3 / 95 \text { to } \\
15 / 4 / 95\end{array}$ & $\begin{array}{c}\text { Period } \\
5 \\
15 / 4 / 95 \text { to } \\
1 / 6 / 95\end{array}$ & $\begin{array}{c}6 \\
1 / 6 / 95 \text { to } \\
15 / 7 / 95\end{array}$ & $\begin{array}{c}7 \\
15 / 7 / 95 \text { to } \\
1 / 9 / 95\end{array}$ & $\begin{array}{c}8 \\
1 / 9 / 95 \text { to } \\
15 / 10 / 95\end{array}$ & $\begin{array}{c}9 \\
15 / 10 / 95 \text { to } \\
11 / 12 / 95\end{array}$ \\
\hline Input & 17.1 & 23.4 & 37.8 & 27.4 & 10.6 & 6.8 & 4.4 & 5.2 & 7.4 \\
\hline Release & 2.4 & 0.0 & 0.0 & 0.7 & 0.2 & 0.7 & 0.3 & 0.0 & 0.0 \\
\hline Retention & 9.0 & 0.0 & 0.0 & 6.6 & 1.5 & 2.6 & 1.5 & 0.0 & 0.0 \\
\hline \multicolumn{10}{|l|}{ Net export } \\
\hline Surface layer & 10.8 & 23.8 & 39.2 & 24.1 & 10.2 & 5.5 & 3.2 & 5.9 & 7.7 \\
\hline Bottom layer & -0.3 & -0.9 & -0.9 & -0.7 & -0.6 & -0.2 & 0.1 & -0.5 & -0.6 \\
\hline Difference & 0.0 & 0.5 & -0.5 & -1.9 & -0.3 & -0.4 & 0.0 & -0.1 & 0.3 \\
\hline
\end{tabular}




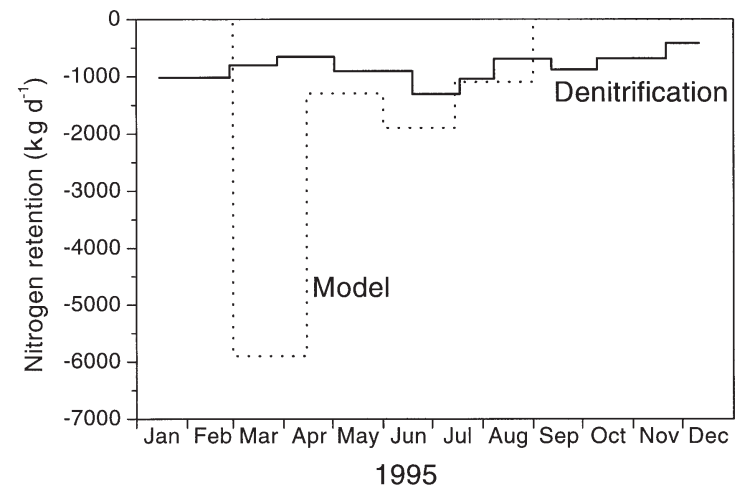

Fig. 8. Nitrogen retention for each of the 9 periods estimated by hydrodynamic modelling (Model) compared with flux measurements in Randers Fjord, 1995

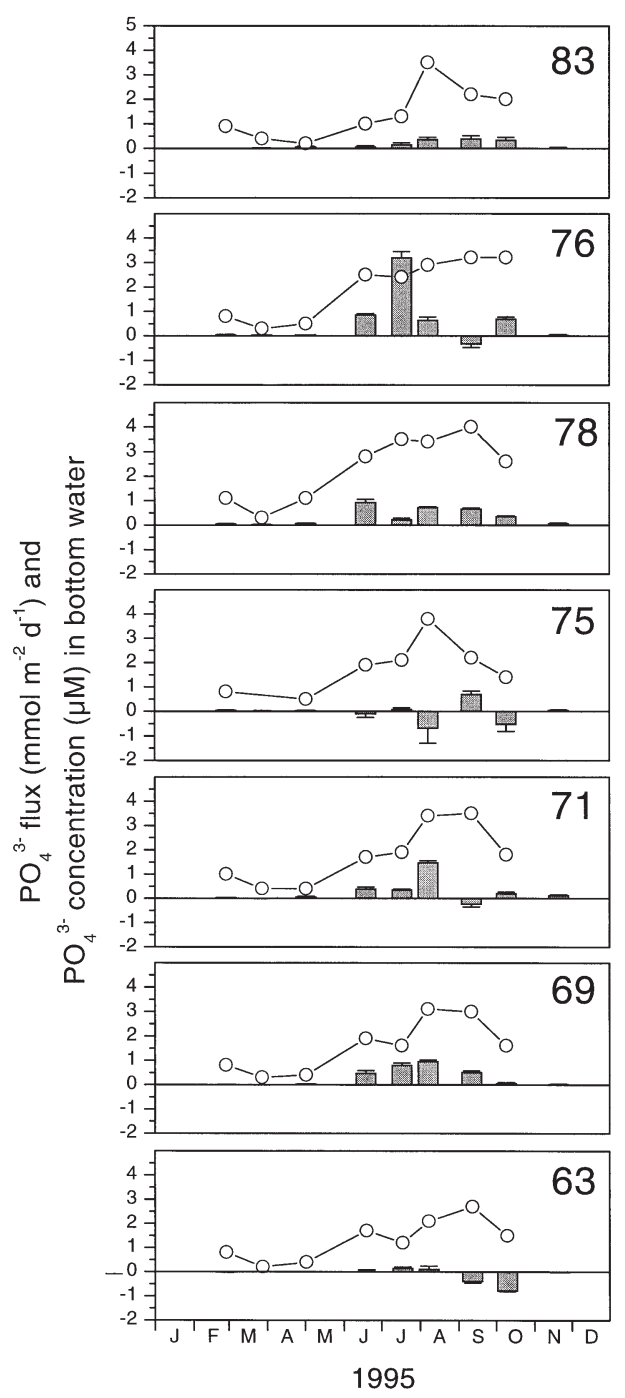

Fig. 9. Phosphorus fluxes and phosphorus concentrations in bottom water for 7 stations in Randers Fjord, 1995 (bars). (O) In situ $\mathrm{PO}_{4}{ }^{3-}$ concentrations of the water column. Error bars $=$ SE $(n=5)$
Fjord (Uggelhuse and Mellerup) contributed most significantly to the total estuary phosphorus release (Table 1). Significant phosphorus uptake of 0.7 to $0.8 \mathrm{mmol} \mathrm{m} \mathrm{m}^{-2} \mathrm{~d}^{-1}$ was found in the outer part of Randers Fjord (Udbyhøj) and in the navigation channel in autumn, which is indicative of oxic sediments. Occasional phosphorus uptake was also observed in the middle of the estuary.

The efflux of phosphorus was low $\left(<0.1 \mathrm{mmol} \mathrm{P} \mathrm{m}^{-2}\right.$ $\mathrm{d}^{-1}$ ) until June, indicating the existence of oxic sediment as a consequence of low oxygen consumption. In summer, the mean phosphorus efflux increased to typically $1 \mathrm{mmol} \mathrm{P} \mathrm{m}^{-2} \mathrm{~d}^{-1}$, the maximum value being $3.2 \mathrm{mmol} \mathrm{P} \mathrm{m} \mathrm{P}^{-2} \mathrm{~d}^{-1}$. The efflux declined to below $1 \mathrm{mmol} \mathrm{m} \mathrm{m}^{-2} \mathrm{~d}^{-1}$ in autumn. High concentrations of phosphorus (1 to $4 \mu \mathrm{M}$ ) were observed in the bottom water at all stations in summer and autumn (Fig. 9).

The oxygen uptake for the entire estuary was $3319 \mathrm{t}$ $\mathrm{O}_{2}$ during the study period, being 2 to 3 -fold lower per $\mathrm{km}^{2}$ at the mouth than in shallow areas with high organic content in the middle of Randers Fjord (Table 1). Also, the oxygen consumption in the navigation channel was lower, probably due to the removal of surface sediment by dredging every fourth year. The sediment oxygen uptake peaked in July to October with rates of 60 to $80 \mathrm{mmol} \mathrm{m}^{-2} \mathrm{~d}^{-1}$ (Fig. 6).

\section{Phosphorus retention estimated by hydrodynamic modelling}

The annual mass balance estimated both the freshwater input and output from the surface layer to the Kattegat at $161 \mathrm{t} \mathrm{P} \mathrm{yr}^{-1}$. Atmospheric deposition was estimated at $0.2 \mathrm{t} \mathrm{P} \mathrm{yr}^{-1}$. Estimated annual phosphorus retention was $15 \mathrm{t} \mathrm{P} \mathrm{yr}^{-1}$, corresponding to the net input from the Kattegat to the bottom layer (Fig. 10). In contrast, the mass balance estimated from flux measurements amounted to a net release of $29.7 \mathrm{t} \mathrm{P} \mathrm{yr}^{-1}$ (Table 1). Phosphorus input from freshwater was estimated at 0.22 to $1.12 \mathrm{t} \mathrm{P} \mathrm{d}^{-1}$, and net phosphorus output from the surface layer to the Kattegat occurred continuously, ranging from 0.25 to $1.19 \mathrm{t} \mathrm{P} \mathrm{d}^{-1}$. Phosphorus was also transported in the bottom layer from the Kattegat to the estuary, ranging from 0.02 to $0.10 \mathrm{t} \mathrm{P} \mathrm{d}^{-1}$. The input from the Kattegat was significant, and amounted to as much as $17 \%$ of the freshwater input. Except for 1 period, June to September, the bottomwater net transport was directed from the Kattegat to Randers Fjord, amounting to $0.03 \mathrm{t} \mathrm{d}^{-1}$ (Table 5).

Phosphorus net retention was highest in the inner part of the estuary $\left(7.1 \mathrm{t} \mathrm{P}\right.$, or $\left.5.1 \mathrm{t} \mathrm{P} \mathrm{km}^{-2}\right)$ owing to high input of organic matter. Lower net retention was estimated for the outer two-thirds of the estuary, ranging from 1.2 to $1.8 \mathrm{t} \mathrm{P} \mathrm{km}^{-2}$, due to high release of phos- 
Fig. 10. Phosphorus mass balance (tonnes) for Randers Fjord from 15 January to 11 December 1995 showing sources and sinks. Phosphorus retention and release were calculated on the basis of the hydrodynamic model

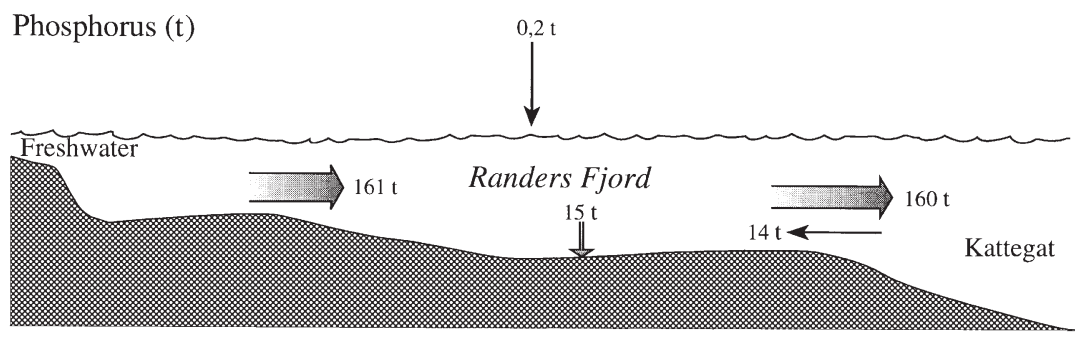

phorus, 6.4 to $9.7 \mathrm{t} \mathrm{P}$, or 1.7 to $2.1 \mathrm{t} \mathrm{P} \mathrm{km} \mathrm{km}^{-2}$, in the middle of the estuary (Table 1).

The mass balance estimated by the hydrodynamic model revealed a phosphorus retention of $0.2 \mathrm{t} \mathrm{P} \mathrm{d}^{-1}$ during the November 1994 calibration period (Table 5). In winter retention was low; in contrast, it was significant ( 0.2 to $0.3 \mathrm{t} \mathrm{P} \mathrm{d}^{-1}$ ) from March to June 1995, when sedimentation of allochthonous material and estuarine phytoplankton was high. These results did not fit with the phosphate fluxes, since sediment phosphate uptake was not observed during the same period (Fig. 9). A net phosphorus release of $0.1 \mathrm{t} \mathrm{P} \mathrm{d}^{-1}$ was observed from July to October, and sediment studies also revealed maximum phosphate efflux (0.3 to $0.4 \mathrm{t} \mathrm{P}$ $\mathrm{d}^{-1}$ ) in summer (Fig. 11, Table 5). Significant differences in phosphorus retention and release were recorded from the head to the mouth of Randers Fjord.

\section{DISCUSSION}

\section{Nitrogen retention}

Nitrogen retention in Randers Fjord estimated by hydrodynamic modelling was $460 \mathrm{t} N$, or $10 \%$ of the freshwater input. Retention was estimated for each sub-area and was positively correlated with water residence time $\left(r^{2}=0.88\right)$, which is consistent with the finding of Nixon et al. (1996) and data from different Danish estuaries (Borum 1996, Dalsgaard et al. 2000).
Retention of nitrogen estimated by hydrodynamic modelling and direct measurements compared well, with values of 10 and $6 \%$, respectively. Although differences in the budgets for the hydrodynamic model were estimated for the individual periods (Table 4), the lower retention obtained by direct measurements cannot be ascribed to modelling inaccuracy. The inaccuracy was significantly lower than half the retention value. The major difference between the 2 estimates is due to the fact that hydrodynamic modelling includes all processes involving nitrogen retention in the estuary, i.e. denitrification, sedimentation and burial. In

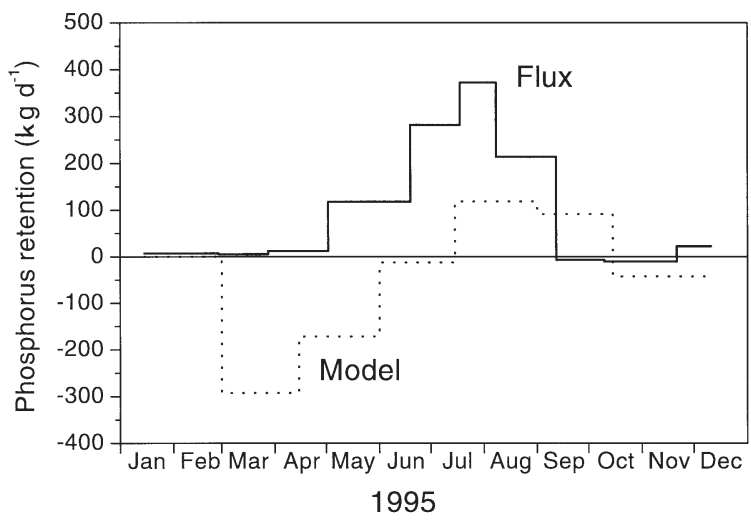

Fig. 11. Phosphorus retention and release for each of the 7 periods estimated by hydrodynamic modelling (Model) compared with flux measurements in Randers Fjord, 1995

Table 5. Phosphorus mass balance ( $\mathrm{t} \mathrm{d}^{-1}$ ) for each of the 9 simulation periods from 1 November 1994 to 11 December 1995. Difference expresses the inaccuracy of the model estimation

\begin{tabular}{|c|c|c|c|c|c|c|c|c|c|}
\hline Parameter & $\begin{array}{c}1 \\
1 / 11 / 94 \text { to } \\
1 / 12 / 94\end{array}$ & $\begin{array}{c}2 \\
1 / 12 / 94 \text { to } \\
15 / 1 / 95\end{array}$ & $\begin{array}{c}3 \\
15 / 1 / 95 \text { to } \\
1 / 3 / 95\end{array}$ & $\begin{array}{c}4 \\
1 / 3 / 95 \text { to } \\
15 / 4 / 95\end{array}$ & $\begin{array}{c}\text { Period } \\
5 \\
15 / 4 / 95 \text { to } \\
1 / 6 / 95\end{array}$ & $\begin{array}{c}6 \\
1 / 6 / 95 \text { to } \\
15 / 7 / 95\end{array}$ & $\begin{array}{c}7 \\
15 / 7 / 95 \text { to } \\
1 / 9 / 95\end{array}$ & $\begin{array}{c}8 \\
1 / 9 / 95 \text { to } \\
15 / 10 / 95\end{array}$ & $\begin{array}{c}9 \\
15 / 10 / 95 \text { to } \\
11 / 12 / 95\end{array}$ \\
\hline Input & 0.615 & 0.678 & 1.118 & 0.745 & 0.433 & 0.320 & 0.225 & 0.310 & 0.325 \\
\hline Release & 0.033 & 0.014 & 0 & 0.052 & 0.066 & 0.201 & 0.118 & 0.091 & 0 \\
\hline Retention & 0.220 & 0.033 & 0 & 0.345 & 0.238 & 0.214 & 0 & 0 & 0.043 \\
\hline Net export & & & & & & & & & \\
\hline Surface layer & 0.470 & 0.749 & 1.188 & 0.570 & 0.291 & 0.248 & 0.260 & 0.497 & 0.390 \\
\hline Bottom layer & -0.056 & -0.094 & -0.098 & -0.070 & -0.037 & -0.017 & 0.034 & -0.052 & -0.055 \\
\hline Difference & 0.013 & 0.003 & 0.028 & -0.048 & 0.007 & 0.076 & 0.049 & -0.044 & -0.053 \\
\hline
\end{tabular}


contrast, direct measurements only included denitrification. We assume that sedimentation, and probably burial, of organic nitrogen is responsible for the difference between the 2 methods, as it is not included in the direct measurement based on retention.

Even though the difference between mass balances estimated by the 2 independent methods was small on an annual scale, large differences occurred on a monthly scale (Fig. 8). The main discrepancy was observed in spring when retention estimated by hydrodynamic modelling was 8 times higher than the measured denitrification. The high retention value can be ascribed to sedimentation of organic matter from the River Gudenå, which transports phytoplankton and other organic compounds from upstream lakes (Andersen 1994). The nitrogen input from the River Gudenå was extremely high during winter and early spring, up to $1150 \mathrm{t} \mathrm{N} \mathrm{mo}^{-1}$. Nitrogen retention was 2 times higher in the inner part of the estuary compared with the outermost sub-area (Table 1), this also being indicative of high sedimentation.

The results of the present study revealed significant spatial and temporal variations in retention and release of nitrogen and phosphorus in Randers Fjord. Furthermore, the input of nitrogen and phosphorus from freshwater was highly variable from winter to summer. Our results indicate that comprehensive investigations of nutrient input from freshwater as well as estuarine transports are needed to obtain reliable annual estimates. Mortazavi et al. (2000) estimated annual denitrification for the large $\left(260 \mathrm{~km}^{2}\right)$ estuary Apalachicola Bay on the basis of 9 sampling dates at a single station. The results seemed to give a fairly accurate picture of temporal variation, whereas no evidence of spatial variation could be found.

\section{Denitrification}

The annual denitrification rate recorded in the present study is to our knowledge the highest rate published for estuaries. Annual denitrification was $140 \mathrm{~kg}$ $\mathrm{ha}^{-1} \mathrm{yr}^{-1}$ in Randers Fjord, or 5 to 10 -fold higher than the rates of 14 to $30 \mathrm{~kg} \mathrm{ha}^{-1} \mathrm{yr}^{-1}$ reported from other Danish estuaries (Nielsen et al. 1995, Christensen et al. 1998). Denitrification rates in Randers Fjord also exceeded the rates of 80 to $110 \mathrm{~kg} \mathrm{ha}^{-1} \mathrm{yr}^{-1}$ reported from estuaries loaded with sewage (Nowicki et al. 1997). Several factors have been shown to influence denitrification, such as temperature, the concentration of nitrate in the water column, organic input to the sediment, benthic algae, bottom fauna activity, salinity and water residence time (e.g. Sundbäck \& Granéli 1988, Kristensen et al. 1991, Pelegri et al. 1994, Nielsen et al. 1995, Rysgaard et al. 1995, Nixon et al. 1996,
Nowicki et al. 1997, Krause-Jensen et al. 1999, Rysgaard et al. 1999).

Randers Fjord was characterised by extremely high nitrogen concentrations, with mean values of 90 and $200 \mu \mathrm{mol} \mathrm{N}{ }^{-1}$; compared with 34 other Danish estuaries, total nitrogen concentrations were among the highest during both winter and summer (Jensen et al. 1997, Conley et al. 2000). The nitrogen loading was twice the maximum values presented for estuaries in North America, even though these included estuaries loaded with sewage (Nowicki et al. 1997). The high nitrate concentrations stimulated denitrification in Randers Fjord compared with other estuaries with lower nitrate concentrations.

Organic matter stimulates the activity of denitrifying bacteria, and Nowicki et al. (1997) found a positive correlation of denitrification rates with sediment organic content in sewage-loaded estuaries. High organic loading (3000 t BOD $\mathrm{yr}^{-1}$ ) resulted in high organic content of the sediment ( 7 to $15 \%$ ignition loss in the inner part of Randers Fjord) due to sedimentation of allochthonous material, while ignition loss was low (1 to $2 \%$ ) at the mouth of Randers Fjord (Table 2). However, the organic content was not correlated with annual measurements of denitrification in Randers Fjord $\left(\mathrm{r}^{2}<0.02\right)$.

Burrowing bottom fauna strongly affects the sediment water solute-exchange and stimulates denitrification (Aller 1988, Kristensen et al. 1991, Pelegri et al. 1994, Rysgaard et al. 1995). Pelegri et al. (1994) showed that $D_{\mathrm{n}}$ and $D_{\mathrm{w}}$ were enhanced by factors 3 and 5, respectively, at high abundance (20000 individuals $\mathrm{m}^{-2}$ ) of the bottom fauna species Corophium volutator. The abundance of bottom fauna was also high (5000 to 15000) in Randers Fjord during 1990 to 1995 (Nielsen et al. 1993, Sømod unpubl. data), although significant reductions in bottom fauna were observed, especially in 1996 in the middle of Randers Fjord (Sømod et al. 1999). The bottom fauna was dominated by Corophium spp. and Nereis diversicolor. Using the relationship between $D_{\mathrm{n}}$ and $D_{\mathrm{w}}$ and bottom-fauna abundance from Pelegri et al. (1994), total denitrification may have been increased by a factor of 2 due to irrigation of bottom fauna in Randers Fjord.

Thus, several factors stimulated denitrification rates in Randers Fjord: high nitrogen concentrations in the water column, high organic loading, abundant bottom fauna and the rapid exchange of oxic water, all contributing to the very high denitrification rates.

\section{Phosphorus retention}

Retention and release of phosphorus in Randers Fjord during the investigation period were estimated 
at 39 and $24 \mathrm{t} \mathrm{P}$, respectively, or a net retention of $15 \mathrm{t}$ P. All 5 sub-areas showed both retention and release of phosphorus, and all had an annual net retention of phosphorus. Phosphorus retention per $\mathrm{km}^{2}$ was higher in the inner part of Randers Fjord, indicating that sedimentation of organic matter from freshwater flocculates in saline water. Sedimentation of organic matter has generally been observed in estuaries with high organic loading owing to the flocculation of particles in saline water (Howarth et al. 1995).

Phosphorus flux measurements showed a net release of $30 \mathrm{t} \mathrm{P} \mathrm{yr}^{-1}$. The direct measurements included only uptake and release of $\mathrm{PO}_{4}{ }^{3-}$ from the sediment, while all processes involving retention of $\mathrm{PO}_{4}{ }^{3-}$ or organic phosphorus were included in estimates calculated by the hydrodynamic model. The significant difference between the estimates of retention may partly be ascribed to sedimentation of allochthonous organic matter. Retention of phosphorus was also highest in the inner part of the estuary, where flocculation increased sedimentation.

The discrepancy was large on an annual as well as on a seasonal scale. The hydrodynamic model showed high phosphorus retention during spring, corresponding estimates being obtained for nitrogen. Spring retention of nitrogen and phosphorus corresponded to input of organic matter with a high molar N:P ratio of 46:1 during the sedimentation event (Figs 8 \& 11). In spring, both retention and release of phosphorus were estimated by the hydrodynamic model. Spring net retention of phosphorus (1 March to 1 June) amounted to 21 t P (Table 5), explaining half the annual discrepancy between the 2 methods used. Following sedimentation of organic matter, gradual release of phosphorus was estimated in the succeeding months by both flux measurements and hydrodynamic modelling. The summer release of phosphorus estimated by flux measurements was significantly higher than that estimated by hydrodynamic modelling, probably due to delayed degradation of imported organic matter.

Phosphate fluxes showed substantial seasonal and spatial variability in release and uptake in Randers Fjord. Sediment efflux of phosphate is mainly regulated by $\mathrm{PO}_{4}{ }^{3-}$ release by degradation of organic matter; additionally, oxidised Fe compounds in the surface sediment in the form of iron-bound $\mathrm{PO}_{4}{ }^{3-}$ are rapidly mobilised in anoxic sediments (Howarth et al. 1995, Jensen et al. 1995), although reversion of the process may be prolonged at low Fe/P concentrations in estuarine water (Gunnars \& Blomqvist 1997). However, the release of $\mathrm{PO}_{4}{ }^{3-}$ was not significantly correlated with oxygen consumption by the sediment in Randers Fjord $\left(\mathrm{r}^{2}=0.41\right)$. Benthic microalgae or mats of macroalgae with net production may indirectly influence the $\mathrm{PO}_{4}{ }^{3-}$ flux by changing the oxygen conditions in shallow coastal areas (Sundbäck \& Granéli 1988, KrauseJensen et al. 1999). In the outer part of the estuary, $\mathrm{PO}_{4}{ }^{3-}$ is probably assimilated by benthic microalgae, as indicated by the higher $\mathrm{PO}_{4}{ }^{3-}$ uptake in the lightincubated sediment cores, and favourable light conditions at the sediment surface.

No strong correlation between $\mathrm{PO}_{4}{ }^{3-}$ release and salinity was found $\left(\mathrm{r}^{2}=0.48\right)$, and the lowest flux rates were measured at the innermost and outermost stations and in the navigation channel. An inverse relationship between total sediment phosphorus concentrations and salinity has generally been found in estuaries (Upchurch et al. 1974, Strom \& Biggs 1982, Sundareshwar \& Morris 1999). The low release of $\mathrm{PO}_{4}{ }^{3-}$ in the inner part of the fjord and in the navigation channel can probably be explained by regular removal of sediment by dredging.

\section{Simple models versus direct measurements and hydrodynamic modelling}

Few studies have estimated retention by parallel and truly independent methods (Nielsen et al. 1995, Mortazavi et al. 2000). The present study, employing both flux measurements and hydrodynamic models, allows comparison of the 2 estimates and discussion of whether complex models or direct measurements may be substituted by simple models. Application of simple models would dramatically reduce the investigation efforts and increase their implementation in actual management.

Nixon et al. (1996) presented empirical models for nitrogen and phosphorus retention as a function of freshwater residence time: \% total $\mathrm{N}$ exported = $-27.0 \log \left(R_{\mathrm{w}}\right)+64.8$ and $\%$ total $\mathrm{P}$ exported $=$ $-31.83\left(R_{\mathrm{w}}\right)+80.8$, where $R_{\mathrm{w}}$ is freshwater residence time in months ( $6 \mathrm{~d}=0.2 \mathrm{mo}$ ). The nitrogen model predicted 1.6 times higher nitrogen retention and a phosphorus release of $3 \%$ in contrast to the $9 \%$ retention estimated by the present hydrodynamic model. The nitrogen model presented by Nixon et al. has also been supported by data from other Danish estuaries (Borum 1996, Dalsgaard et al. 2000). Thus, the nitrogen model compared retention fairly well, but the phosphorus model estimated release instead of retention.

Christensen et al. (1990) estimated the denitrification of $\mathrm{NO}_{3}{ }^{-}$in the water column, and $D_{\mathrm{w}}$ for unvegetated sediments in streams by means of the following equation:

$$
D_{\mathrm{w}}=F_{\mathrm{O}_{2}} \times 0.8 \times\left[\left(\sqrt{1+0.82 \times \frac{C_{\mathrm{NO}_{3}}}{C_{\mathrm{O}_{2}}} \times \frac{1}{0.8}}\right)-1\right]
$$

where $F_{\mathrm{O}_{2}}$ is the sediment $\mathrm{O}_{2}$ consumption rate and $\mathrm{C}_{\mathrm{O}_{2}}$ and $\mathrm{C}_{\mathrm{NO}_{3}}$ are the concentrations of $\mathrm{O}_{2}$ and $\mathrm{NO}_{3}{ }^{-}$. 
The coefficient 0.8 is the ratio between volume-specific $\mathrm{O}_{2}$ consumption and volume-specific denitrification activity, while the 0.82 coefficient is the ratio between the diffusion coefficients for $\mathrm{NO}_{3}{ }^{-}$and $\mathrm{O}_{2}$ (Nielsen et al. 1990). The model assumption is that denitrification and $\mathrm{O}_{2}$ uptake are controlled by diffusional processes and that $\mathrm{NO}_{3}^{-}$is only removed by denitrification, implying that removal of $\mathrm{NO}_{3}{ }^{-}$by microbenthic algae assimilation or dissimilative reduction of nitrate to ammonia is insignificant.

When applied on the entire data set, the model explained less than $3 \%$ of the variation in $D_{\mathrm{w}}$ in Randers Fjord $\left(\mathrm{r}^{2}=0.027\right)$. Probably, the presence of microbenthic algae at most stations, as indicated from our $\mathrm{O}_{2}$ flux data from light and dark incubations, contributed to this discrepancy (cf. Pind et al. 1997). Good agreement between measured and modelled denitrification data at $\operatorname{Stn} 75\left(r^{2}=0.98\right)$, where benthic photosynthesis was absent due to light limitations, supports this hypothesis. It is furthermore likely that benthic fauna such as Corophium sp., which was highly abundant in Randers Fjord (Sømod et al. 1999), may disrupt the relationship between $\mathrm{O}_{2}$ uptake and denitrification proposed by the model by affecting the ratio between $\mathrm{O}_{2}$ uptake and the volume-specific denitrification activity. Peligri et al. (1994) thus demonstrated that denitrification was stimulated by approximately 3 times more than $\mathrm{O}_{2}$ uptake in amphipod burrows. Dissimilatory $\mathrm{NO}_{3}{ }^{-}$reduction to $\mathrm{NH}_{4}{ }^{+}$is not a quantitatively important process in Randers Fjord (National Environmental Research Institute unpubl. data), and will consequently not interfere with the model presumptions. Dissimilative reduction of nitrate has little quantitative importance in most estuaries and has only been proven important in sediment extremely highly loaded with organic matter from sea cage or shellfish farming (Kaspar et al. 1988, Gilbert et al. 1997, Christensen et al. 2000).

Seitzinger \& Giblin (1996) demonstrated a positive linear relation between coupled nitrification-denitrification, $D_{\mathrm{n}}$, and sediment oxygen uptake for continental shelf sediments. In Randers Fjord, however, there was no such linear dependency on $D_{\mathrm{n}}$ by the $\mathrm{O}_{2}$ uptake $\left(\mathrm{r}^{2}<0.07\right)$. A linear relation between $\mathrm{O}_{2}$ uptake and $D_{\mathrm{n}}$ on an annual basis presumes at least $\mathrm{NH}_{4}{ }^{+}$limitation of nitrification and a constant ratio between $\mathrm{O}_{2}$ uptake and benthic net mineralization throughout the year. This was apparently not the case in Randers Fjord. Previous studies have shown that nitrification is limited by oxygen in sediments with high $\mathrm{O}_{2}$ uptake rates (Caffrey et al. 1993, Sloth et al. 1995). Thus, it may be expected that an approximate linear relationship between $D_{\mathrm{n}}$ and $\mathrm{O}_{2}$ uptake only exists for a limited range of sediment oxygen-uptake rates. In addition, presence of irrigating fauna (e.g. Corophium sp.) in the sediments of Randers Fjord may also affect the ratio of coupled nitrification-denitrification to benthic $\mathrm{O}_{2}$ uptake, as shown by Pelegri et al. (1994), further contributing to the absence of correlation between $D_{\mathrm{n}}$ and $\mathrm{O}_{2}$ uptake rates in Randers Fjord.

In consequence, the existing models for nitrogen and phosphorus retention and denitrification did not fit well with the data from Randers Fjord. Of all empirical models described, the model for nitrogen retention presented by Nixon et al. (1996) provided the best estimate for nitrogen retention. Denitrification could not be explained by $\mathrm{NO}_{3}{ }^{-}$concentrations in the water column and $\mathrm{O}_{2}$ uptake by sediment, components used for other aquatic systems. Regulation of denitrification seemed to be more complex in Randers Fjord, probably due to a complex matrix of interactions between the denitrification process, algae and animal activity. Flux and direct denitrification measurements or complex modelling need therefore to be applied to obtain reliable estimates.

Empirical models are valuable for quantification of nutrient retention in general, but more information than input of nutrients and water residence time is needed if they are to be applied on an individual estuary basis.

From a management point of view, our findings suggest that retention should be estimated by either mass balance or direct measurements in each individual estuary. The 2 methods gave different estimates of especially phosphorus, since phosphorus sedimentation can be high in estuaries with freshwater input of organic matter. Mass balance provides an overall estimate of the 'filter effect' in the estuary, while information about nutrient sink-sources in the sediment is obtained by flux measurements. Direct measurements are recommended to elucidate the response of nutrient loading or shifts in biological structure in estuaries.

Acknowledgements. We thank Bent Boel Sørensen, Verner Dam, Jørgen Erik Larsen and Peter Boller for their skillful and enthusiastic assistance in the field, and Marlene Skjærbæk for helpful laboratory assistance. Anne Mette Poulsen is acknowledged for manuscript assistance.

\section{LITERATURE CITED}

Aller RC (1998) Benthic fauna and biogeochemical processes in marine sediments: the role of burrow structure. In: Blackburn TH, Sørensen J (eds) Nitrogen cycling in coastal marine environments. John Wiley \& Sons Ltd, Chichester, p 301-338

Andersen JM (1994) Water quality management in the River Gudenå, a Danish lake-stream-estuary system. Hydrobiologia 275/276:499-507

Bach HK, Jensen JK (1994) Modelling of water quality of a proposed impounded lake of a tidally influenced river. Ecol Model 74:77-90 
Borum J (1996) Shallow waters and land/sea boundaries. In: Jørgensen BB, Richardson K (eds) Eutrophication in coastal marine ecosystems. American Geophysical Union, Washington DC, p 179-203 (Coast Estuar Stud)

Bower E, Holm-Hansen A (1980) A salicylate-hypochlorite method for determining ammonia in seawater. Can J Fish Aquat Sci 37:794-798

Boynton WR, Garber JH, Summers R, Kemp WM (1995) Inputs, transformations and transport of nitrogen and phosphorus in Chesapeake Bay and selected tributaries. Estuaries 18:285-314

Caffrey JM, Sloth NP, Kaspar HF, Blackburn TH (1993) Effect of organic loading on nitrification and denitrification in a marine sediment microcosm. FEMS Microbiol Ecol 12: 159-167

Christensen PB, Nielsen LP, Sørensen J, Revsbech NP (1990) Denitrification in nitrate-rich streams: diurnal and seasonal variation related to benthic oxygen metabolism. Limnol Oceanogr 35:640-651

Christensen PB, Møhlenberg F, Lund-Hansen LC, Borum J, Christiansen C, Larsen SE, Hansen ME, Andersen J, Kierkegaard J (1998) The Danish marine environment: has action improved its state? Ministry of Environment and Energy, Danish Environmental Protection Agency, Copenhagen, Denmark (Mar Res Rep No 62)

Christensen PB, Rysgaard S, Sloth NP, Dalsgaard T, Schwærter S (2000) Sediment mineralization, nutrient fluxes, denitrification and dissimilatory nitrate reduction to ammonia in an estuarine fjord with sea cage trout farms. Aquat Microb Ecol 21:73-84

Conley DJ (2000) Biogeochemical nutrient cycles and nutrient management strategies. Hydrobiologia 410:87-96

Conley DJ, Kaas H, Møhlenberg F, Rasmussen B, Windolf J (2000) Characteristics of Danish estuaries. Estuaries 23: 820-837

Dalsgaard T, Christensen PB, Rysgaard S, Risgaard-Petersen N (2000) Denitrification in Danish estuaries. In: Lomstein B (ed) Marine environments into the millenium. Olsen \& Olsen, Fredensborg, p 101-118 (in Danish)

Ecological Modelling Centre (1992) MIKE 12, a short description. Ecological Modelling Centre, Hørsholm

Gilbert F, Souchu P, Bianchi M, Bonin P (1997) Influence of shellfish farming activities on nitrification, nitrate reduction to ammonia and denitrification at the water-sediment interface of the Thau Lagoon, France. Mar Ecol Prog Ser 151:143-153

Granéli E, Granéli W, Rydberg L (1986) Nutrient limitation at the ecosystem and phytoplankton community level in the Laholm Bay, south-east Kattegat. Ophelia 26:181-194

Grasshof K, Erhardt M, Kremling K (1983) Methods of seawater analysis, 2nd edn. Verlag Chemie, Weinheim

Greensberg A (1992) Standard methods for examination of water and wastewater, 18th edn. American Public Health Association, Washington, DC

Gunnars A, Blomqvist S (1997) Phosphate exchange across the sediment-water interface when shifting from anoxic to oxic conditions - an experimental comparison of freshwater and brackish-marine systems. Biogeochemistry 37: 203-226

Howarth RW, Jensen HS, Marino R, Postma H (1995) Transport to and processing of $\mathrm{P}$ in the near shore and oceanic waters. In: Tiessen $\mathrm{H}$ (ed) Phosphorus in the global environment. John Wiley \& Son Ltd, New York, p 322-345

Howarth RW, Billen G, Swaney D, Townsend A, Jaworski N, Lajtha K, Downing JA, Elmgren R, Caraco N, Jordan T, Berendse F, Freeney J, Kudeyarov V, Murdoch P, ZhaoLiang Z (1996) Regional nitrogen budgets and riverine $N$
\& P fluxes for the drainages to the North Atlantic Ocean: natural and human influences. Biogeochemistry 35:5-139

Jenkins MC, Kemp M (1984) The coupling of nitrification and denitrification in two estuarine sediments. Limnol Oceanogr 29:609-619

Jensen HS, Mortensen PB, Andersen FØ, Rasmussen E, Jensen A (1995) Phosphorus cycling in a coastal marine sediment, Aarhus Bay, Denmark. Limnol Oceanogr 40:908-917

Jensen JN, Ertebjerg G, Rasmussen B, Dahl K, Levinsen $\mathrm{H}_{\text {, }}$ Lisbjerg D, Nielsen TG, Krause-Jensen D, Middelboe AL, Svendsen LM, Sand-Jensen K (1997) Marine areas. Ministsry of Environment and Energy, National Environmental Research Institute, Denmark (Rep No. 213)

Kamp-Nielsen L (1992) Benthic-pelagic coupling of nutrient metabolism along an estuarine eutrophication gradient. Hydrobiologia 235/236:457-470

Kaspar HF, Hall GH, Hoplland AJ (1988) Effects of sea cage farming on sediment nitrification and dissimilatory nitrate reduction. Aquaculture 70:333-344

Krause-Jensen D, Christensen PB, Rysgaard S (1999) Oxygen and nutrient dynamics within mats of the filamentous macroalgae Chaetomorpha linum. Estuaries 22:31-38

Kristensen E, Jensen MH, Aller RC (1991) Direct measurements of dissolved inorganic nitrogen exchange and denitrification in individual polychaete (Nereis virens) burrows. J Mar Res 49:355-377

Mortazavi B, Iverson RL, Huang W, Lewis GF, Caffrey JM (2000) Nitrogen budgets of Apalachicola Bay, Florida, a bar-built estuary in the northeastern Gulf of Mexico. Mar Ecol Prog Ser 195:1-14

Nedwell DB, Trimmer M (1996) Nitrogen fluxes through the upper estuary of the Great Ouse, England, the role of the bottom sediments. Mar Ecol Prog Ser 142:273-286

Nielsen LP (1992) Denitrification in sediment determined from nitrogen isotope pairing. FEMS Microbiol Ecol 86: 357-362

Nielsen LP, Christensen PB, Revsbech NP, Sørensen J (1990) Denitrification and oxygen respiration in biofilms studied with a microsensor for nitrous oxide and oxygen. Microb Ecol 19:63-72

Nielsen K, Sømod B, Hansen DF (1993) Eutrophication of Randers Fjord estuary, Denmark - deteriorations and improvements (1900-1991). Europ Water Pollut Contr 3:44-51

Nielsen K, Nielsen LP, Rasmussen P (1995) Estuarine nitrogen retention independently estimated by the denitrification rate and mass balance methods: a study of Norsminde Fjord, Denmark. Mar Ecol Prog Ser 119:275-283

Nixon SW, Ammerman JW, Atkinson LP, Berounsky WM, Billen G, Boicourt WC, Boynton WR, Church TM, Ditoro DM, Elmgren R, Garber JH, Giblin AE, Hahnke RA, Owens NJP, Pilson MEQ, Seitzinger SP (1996) The fate of nitrogen and phosphorus at the land-sea margin of the North Atlantic Ocean. Biogeochemistry 35:141-180

Nowicki BL, Requintina E, Van Keuren D, Kelly JR (1997) Nitrogen losses through sediment denitrification in Boston Harbor and Massachusetts Bay. Estuaries 20:626-639

Pelegri SP, Nielsen LP, Blackburn TH (1994) Denitrification in estuarine sediment stimulated by irrigation activity of the amphipod Corophium volutator. Mar Ecol Prog Ser 105: 285-290

Pind A, Risgaard-Petersen N, Revsbech NP (1997) Denitrification and microphytobenthic $\mathrm{NO}_{3}{ }^{-}$consumption in a Danish lowland stream: diurnal and seasonal variation. Aquat Microb Ecol 12:275-284

Rosenberg R, Elmgren R, Fleischer S, Johnsson P, Persson G, Dahlin M (1990) Marine eutrophication case studies in Sweden. Ambio 19:102-108 
Risgaard-Petersen N, Rysgaard S, Revsbech NP (1993) A sensitive assay for determination of ${ }^{14} \mathrm{~N} /{ }^{15} \mathrm{~N}$ isotope distribution in $\mathrm{NO}_{3}{ }^{-}$. J Microbiol Meth 17:155-164

Risgaard-Petersen N, Rysgaard S (1995) Nitrate reduction in sediments and waterlogged soil measured by ${ }^{15} \mathrm{~N}$ techniques. In: Alef K, Nannipieri P (eds) Methods in applied soil microbiology and biochemistry. Academic Press London, p 287-310

Risgaard-Petersen N, Nielsen LP, Blackburn TH (1998) Simultaneous measurement of benthic denitrification, with the isotope pairing technique and the $\mathrm{N}_{2}$ flux method in a continuous flow-through system. Water Res 32:3371-3377

Rysgaard S, Christensen PB, Nielsen LP (1995) Seasonal variation in nitrification and denitrification in estuarine sediment colonized by benthic microalgae and bioturbating infauna. Mar Ecol Prog Ser 126:111-121

Rysgaard S, Thastum P, Dalsgaard T, Christensen PB, Sloth NP (1999) Effects of salinity on $\mathrm{NH}_{4}{ }^{+}$adsorption capacity, nitrification, and denitrification in Danish estuarine sediments. Estuaries 22:21-30

Ryther JH, Dunstan WM (1971) Nitrogen, phosphorus and eutrophication in the coastal marine environment. Science 171:1008-1013

Seitzinger SP (1988) Denitrification in freshwater and in coastal marine ecosystems: ecological and geochemical significance. Limnol Oceanogr 33:702-724.

Seitzinger SP (1990) Denitrification in aquatic sediments. In: Revsberch NP, Sørensen J (eds) Denitrification in soil and sediments, Plenum Press, New York, p 301-321

Seitzinger SP, Giblin AE (1996) Estimating denitrification in North Atlantic continental shelf sediments. Biogeochemistry 35:235-260

Editorial responsibility: Otto Kinne (Editor),

Oldendorf/Luhe, Germany
Sloth NP, Blackburn H, Hansen LS, Risgaard-Petersen N, Lomstein BA (1995) Nitrogen cycling in sediments with different organic loading. Mar Ecol Prog Ser 116:163-170

Sømod B, Larsen JE, Hansen DF, Düvel L, Andersen P (1999) The aquatic environment in Randers Fjord. County of Aarhus, Aarhus (in Danish)

Strickland JDH, Parsons TR (1972) A practical handbook of seawater analysis, 2nd edn Bull Fish Res Board Can 167: $1-310$

Strom RN, Biggs RB (1982) Phosphorus distribution in sediment of Delaware River estuary. Estuaries 5:95-101

Sundareshwar PV, Morris JT (1999) Phosphorus sorption characteristics of intertidal march sediments along an estuarine salinity gradient. Limnol Oceanogr 44:1693-1701

Sundbäck K, Granéli W (1988) Influence of microphytobenthos on the nutrient flux between sediment and water: a laboratory study. Mar Ecol Prog Ser 43:63-69

Trimmer M, Nedwell DB, Sivyer DB, Malcolm SJ (1998) Nitrogen fluxes through the lower estuary of the river Great Ouse, England: the role of bottom sediments. Mar Ecol Prog Ser 163:109-124

Upchurch JB, Edzwald JK, O'Melia CR (1974) Phosphates in sediments of Pamlico Estuary. Environ Sci Technol 8: 499-504

van Beusekom JEE, de Jonge VN (1998) Retention of phosphorus and nitrogen in the Ems Estuary. Estuaries 21: $527-539$

Water Consult (1997) Randers Fjord-exchange of nutrients and water 1994-95. Aarhus County Council, Water Consult Glumsø (in Danish)

Wulff F, Stigebrandt A, Rahm L (1990) Nutrient dynamics of the Baltic Sea. Ambio 19:126-133

Submitted: July 4, 2000; Accepted: October 18, 2000

Proofs received from author(s): August 28, 2001 